\section{InIIret}

4.2020

Ana Belén Gómez-Bellvís Centro CRÍMINA para el estudio y prevención de la delincuencia

\title{
La disuasión penal en el estado de alarma: Sobre la eficacia de la amenaza del castigo de la desobediencia al confinamiento
}

\begin{abstract}
Sumario
El estado de alarma decretó una obligación de confinamiento a la ciudadanía, cuyo cumplimiento resultaba esencial para evitar la propagación del virus SARS$\mathrm{COV}$-2. El presente trabajo analiza los factores asociados al incumplimiento de esta norma teniendo en cuenta el enfoque de la disuasión, la influencia social, la legitimidad sustantiva y procedimental, y los factores contextuales o ambientales, con el objetivo de proporcionar evidencias sobre qué factores relacionados con el mensaje normativo penal influyen en la decisión del sujeto de infringir. Sobre una muestra de 1312 participantes, los resultados muestran que la certeza percibida de la sanción, la gravedad percibida de la conducta y la actitud de obediencia a la ley aumentan las probabilidades de cumplir con la norma, mientras que la norma social descriptiva y haber sido parado por la policía aumentan las probabilidades de incumplir. Se concluye que para que el modelo basado en la disuasión despliegue su eficacia parece necesario mantener elevados niveles de certeza que son difíciles de asegurar en un contexto diferente, y se discute la posibilidad de promover el cumplimiento normativo aprovechando el potencial preventivo de mensajes normativos basados en los modelos de conducta sociales y del sistema de valores de los individuos.
\end{abstract}

\begin{abstract}
The state of alarm declared an obligatory lockdown of citizens, compliance with which was essential to prevent the spread of the SARS-COV-2 virus. This paper analyses the factors associated with non-compliance with this regulation, taking into account the approach to deterrence, social influence, substantive and procedural legitimacy, and contextual or environmental factors, with the aim of providing evidence on which factors related to the criminal regulatory message Influence the subject's decision to Infringe. On a sample of 1312 participants, the results show that the perceived certainty of the sanction, the perceived seriousness of the behaviour and the attitude of obedience to the law increase the probabilities of complying with the regulation, while the descriptive social norm and having been stopped by the police increase the probabilities of not complying. It is concluded that for the deterrence approach to be effective it seems necessary to maintain high levels of certainty that are difficult to ensure in a different context, and the possibility of promoting compliance by exploiting the preventive potential of regulatory messages based on individual's social role models and value systems is discussed.
\end{abstract}

Title: Criminal deterrence in the state of alarm: on the efficacy of the threat of punishment in the disobedience of lockdown measures

Palabras clave: Estado de alarma, cumplimiento normativo, disuasión, legitimidad, influencia social

Keywords: State of alarm, normative compliance, deterrence, legitimacy, social influence $-$

DOI: $10.31009 /$ InDret.2020.i4.08 


\section{InIDret}

4.2020

Recepción

29/05/2020

Aceptación

22/09/2020

\section{Índice}

1. Justificación del objeto de estudio: cuando la "bala de plata" contra el SARS-COV-2 es el comportamiento conforme a las normas

2. Justificación del enfoque del estudio: los factores asociados al cumplimiento normativo

2.1. El enfoque de la disuasión

2.2. El enfoque de la influencia social

2.3. El enfoque de la legitimidad sustantiva y procedimental

2.4. Otros factores: los factores ambientales o contextuales del cumplimiento del confinamiento como particularidad

2.5. Recapitulación

3. El estudio empírico

3.1. Objetivos e hipótesis

3.2. Muestra

3.3. Variables y procedimiento

4. Resultados

4.1. Estadísticos descriptivos

4.2. Correlaciones bivariadas

4.3. Modelización matemática del incumplimiento

5. Discusión y conclusiones

6. Bibliografía

Anexo I

Anexo II

Este trabajo se publica con una licencia Creative Commons ReconocimientoNo Comercial 4.0 Internacional @) (1) 


\section{Justificación del objeto de estudio: cuando la "bala de plata" contra el SARS-COV-2 es el comportamiento conforme a las normas*}

Pocas esferas de nuestra sociedad saldrán intactas de la pandemia ocasionada por el virus SARS-COV-2. A nivel social, económico y muy probablemente jurídico, todo se verá afectado de un modo u otro por un virus que, conforme a las estadísticas oficiales, ha causado casi 30.000 fallecimientos y cuyas consecuencias devastadoras a cualquier nivel aún no han cesado.

Con el objetivo de evitar su propagación muchos de los Estados adoptaron, desde las primeras fases de la pandemia, normas limitativas de derechos (KOOISTRA et al., 2020; KUIPER, et al., 2020; ROOIJ, et al., 2020; GRAHAM-HARRISON y KUO, 2020), fundamentalmente el de libre circulación, dirigidas a lograr el distanciamiento social y a reducir los contagios. La más significativa de ellas consistió en la imposición a la población de un confinamiento domiciliar (lockdown), como medio de contención eficaz de la difusión del virus (WiLDER-Smith y FreEDMAN, 2020; GREENSTONE y NigAM, 2020). Tal medida fue adoptada en España a través del Real Decreto 463/2020, de 14 de marzo, por el que se declara el estado de alarma para la gestión de la situación de crisis sanitaria ocasionada por el COVID-19 (RD en adelante). El RD vino a establecer, en su artículo 7, la prohibición durante la vigencia del estado de alarma de circular por las vías o espacios públicos salvo para realizar excepcionalmente actividades consideradas esenciales o básicas tales como la adquisición de alimentos, el desplazamiento a centros sanitarios, asistencia al lugar de trabajo, entre otras. El artículo 20 del $\mathrm{RD}$ regulaba el régimen sancionatorio, estableciendo que el incumplimiento o la resistencia a las órdenes de las autoridades competentes en el estado de alarma se sancionaría con arreglo a las leyes, en los términos establecidos en el artículo diez de la L.O. 4/1981, de 1 de junio.

A tenor de lo dispuesto, eran dos las principales conductas sancionables en relación con el confinamiento impuesto, distintas pero relacionadas entre sí. Por un lado, el incumplimiento mismo de la norma, la infracción del confinamiento fuera de los supuestos excepcionales previstos en el artículo 7. Por otro, la resistencia a las órdenes de las autoridades competentes relacionadas con el confinamiento, esto es, fundamentalmente la desobediencia (AMOEDOSouto, 2020). En cuanto a las sanciones aplicables, si bien hay otros instrumentos que posiblemente suscitarían menos dudas y tensiones respecto de las garantías y principios que rigen en el Derecho Penal y en el Administrativo-Sancionador, como la Ley General de Salud Pública (COLOMER BEA, 2020), primaron, por un lado las sanciones a los incumplimientos procedentes del ámbito administrativo por medio de la Ley de Seguridad Ciudadana (L.O 4/2015, de 30 de marzo, en adelante LOSC) y por otro, ya en el ámbito penal, la aplicación del delito de desobediencia (artículo $556 \mathrm{CP}$ ). Así vino a establecerlo el Ministerio de Interior a través de la Orden INT/266/2020, de 15 de marzo, por la que se establecen criterios de actuación para las Fuerzas y Cuerpos de Seguridad en relación con el Real Decreto 463/2020, de 14 de marzo, por el que se declara el estado de alarma para la gestión de la situación de crisis sanitaria

* Autora de contacto: Ana Gómez-Bellvís, ana.gomezb@umh.es. El presente trabajo ha sido realizado en el marco del proyecto "Criminología, evidencias empíricas y Política criminal. Sobre la incorporación de datos científicos para la toma de decisiones en relación con la criminalización de conductas - Referencia: DER2017-86204-R, financiado por la Agencia Estatal de Investigación (AEI)/Ministerio de Ciencia, Innovación y Universidades y la Unión Europea a través del Fondo Europeo de Desarrollo Regional FEDER- "Una manera de hacer Europa". Asimismo, este trabajo ha recibido fondos de las ayudas para contratos predoctorales para la formación de doctores 2018 (FPI) del Ministerio de Ciencia, Innovación y Universidades y con la cofinanciación del Fondo Social Europeo, con referencia PRE2018-083939. 
ocasionada por el COVID-19, que en su artículo quinto dispone que la ciudadanía tiene el deber cívico de colaborar y no obstaculizar la labor de los agentes de la autoridad en el ejercicio de sus funciones, y en caso de no hacerlo establece que podrá recurrirse tanto a los delitos de atentado contra la autoridad, sus agentes y los funcionarios públicos, de resistencia y desobediencia (arts. 550 a $556 \mathrm{CP}$ ), como también al artículo 36.6 de la LOSC que considera como infracción grave la desobediencia o la resistencia a la autoridad o a sus agentes en el ejercicio de sus funciones, cuando no sean constitutivas de delito, así como la negativa a identificarse a requerimiento de la autoridad o de sus agentes o la alegación de datos falsos o inexactos en los procesos de identificación.

Como consecuencia de la aplicación de esta normativa, en España se han producido más de 1.005.187 de propuestas de sanción y más de 8.730 detenidos (Ministerio de Interior, $19 / 05 / 2020)^{1}$, datos que han generado un cierto malestar entre los operadores jurídicos ${ }^{2}$, pero también entre la ciudadanía que ha sido testigo, principalmente a través de los medios de comunicación, de ciertas actuaciones policiales en la aplicación de las correspondientes sanciones y que generan, cuanto menos, algunas dudas o inseguridades jurídicas ${ }^{3}$, interpretaciones que, asimismo, propiciaron que el Ministerio de Interior realizase una Comunicación a los Delegados del Gobierno sobre los procedimientos sancionadores por presunta infracción del artículo 36.6 de la L.O. 4/2015, y criterios para la propuesta de sanción, de 14 de abril.

Más allá de la discusión acerca del alcance constitucional del estado de alarma, la afectación colateral de derechos fundamentales y la diferencia con el estado de excepción (PRESNO LINERA, 2020), la aplicación del régimen sancionatorio del incumplimiento de este estado de alarma ha reabierto y hecho más necesarios distintos debates ético-normativos. Entre ellos destaca el

\footnotetext{
${ }^{1}$ Disponible en: http://www.interior.gob.es/prensa/noticias//asset_publisher/GHU8Ap6ztgsg/content/id/11901184

${ }^{2}$ Es el caso de la Abogacía General del Estado que emitió la Consulta sobre tipificación y competencia administrativa para tramitar y resolver procedimientos sancionables por incumplimiento de las limitaciones impuestas durante el estado de alarma, firmada por Consuelo Castro Rey (Disponible en: http://covid19.femp.es/wp-content/uploads/2020/04/tipificacion-y-competencia-adm-para-tramitar-yresolver-informe-de-la-abogacia-del-estado.pdf), que explicó que "El artículo 36.6 de la Ley Orgánica 4/2015 tipifica una infracción administrativa derivada no de la mera contravención de una norma jurídica (conducta que, como se ha indicado, es reprobable y conlleva unas consecuencias jurídicas propias en Derecho), sino del desconocimiento del principio de autoridad, que entraña un reproche o desvalor adicional. Cuando quien actúa investido legalmente de la condición de autoridad no es obedecido por un particular, esa conducta merece un reproche adicional al que conlleva el previo incumplimiento de la normativa vigente. Por lo expuesto, la infracción de desobediencia precisa necesariamente de un requerimiento expreso e individualizado por parte del agente de la autoridad, que no resulte atendido por el destinatario de dicho requerimiento. Así las cosas, el mero incumplimiento de las limitaciones o restricciones impuestas durante el estado de alarma no puede ser calificado automáticamente como infracción de desobediencia del artículo 36.6 de la Ley Orgánica 4/2015. Dicha infracción concurrirá cuando, habiendo incumplido el particular las limitaciones del estado de alarma, sea requerido para su cumplimiento por un agente de la autoridad, y el particular desatienda dicho requerimiento". En un sentido similar, el auto del Juzgado de Instrucción número 2 de Pontevedra que decretó la puesta en libertad de un detenido por la supuesta comisión de un delito de desobediencia. Disponible en: http://www.poderjudicial.es/cgpi/es/Poder-Judicial/Sala-de-Prensa/Notas-de-prensa/El-juez-decreta-lapuesta-en-libertad-de-un-detenido-en-Pontevedra-por-incumplir-el-confinamiento-

${ }^{3}$ Sería el supuesto, por ejemplo, de la sanción a un ciudadano que fue identificado en la vía pública y alegó la excepción de adquisición de alimentos, pero que, sin embargo, tras requerirle la Policía Local el tique de la compra (había comprado refrescos, chocolate y un paquete de salchichas) los agentes consideraron que su conducta era una burla a la norma de confinamiento y fue sancionado con una multa de 601 euros.
} 
relativo a si es adecuado sancionar penalmente el mero incumplimiento de una norma administrativa, así como los elementos que debe colmar la conducta en concreto para requerir la intervención del Estado desde una rama del ordenamiento jurídico o de otra, esto es, los límites entre la sanción administrativa y el castigo penal (ColOMER BEA, 2020; MAGRo SERVET, 2020; De la Mata Barranco, 2020; Dopico, 2020; Alonso Rimo, 2020). Debate que, a su vez, se relaciona con la antigua discusión sobre la diferencia entre desobediencia grave y leve (JUANATEY DORADO, 1997, 2016) ${ }^{4}$, pero también con otros como el referido a la determinación y concreción de la protección del bien jurídico "principio de autoridad" (CARRETERO-SÁNCHEZ, 2015; Álvarez GarCía y CARRASCO, 2018; AlONSO Rimo, 2020); el relativo a si la respuesta sancionatoria y punitiva en términos de merecimiento es proporcional; y, en relación con esto último, el debate acerca de si la aplicación de la LOSC y las sanciones del artículo 36.6 de la LOSC y sus consecuencias pueden resultar incluso más gravosas que la aplicación del artículo 556 del CP (De la Fuente Cardona, 2018; García Rivas, 2015).

Todas estas discusiones parecen tener como punto de partida la reflexión jurídica respecto a qué tipo de conducta debe sancionarse por vía administrativa o por vía penal (o anteriormente a la reforma del CP de 2015 qué debía sancionarse como delito y como falta), encontrando detrás de su análisis la relación entre el desvalor de acción y el merecimiento de sanción acorde con dicho desvalor para deslindar una de otra. Al fin y al cabo, el legislador ha decidido que una conducta de desobediencia pueda sancionarse por dos vías cualitativamente distintas, ya que la intervención del Derecho penal implica la expresión punitiva más dura del ordenamiento jurídico. Y la única justificación que puede permitir la injerencia del Derecho penal basado en el principio de intervención mínima debe ser que la conducta sobrepase una gravedad cualitativa y un merecimiento de sanción mucho mayor que la conducta que constituye una infracción administrativa. Es cierto, tal y como apuntaba CUERDA ARNAU (2015), que la reforma del Código Penal y de la LOSC de 2015 ha difuminado todavía más los límites de la intervención penal, pero si el legislador ha decidido sancionar el incumplimiento de las normas de conducta en que consiste el confinamiento por vía administrativa y también por vía penal es porque debe haber una diferencia en términos de gravedad y merecimiento entre una y otra que convierta en materialmente legítima la intervención de la rama del ordenamiento jurídico más dura por implicar la afectación de derechos fundamentales. Asimismo, si entendemos que el Derecho penal debe estar orientado a las consecuencias (ORTIZ DE URBINA, 2003), debemos asumir que la razón de su intervención ante este tipo de conductas debe responder a una necesidad preventiva acorde con esa mayor gravedad, una razón de política-criminal como una herramienta de racionalidad instrumental que ponga en relación el objetivo que se persigue y su efectiva consecución (DíEz Ripollés, 2013, AtienZA, 1989; PARedes Castañón, 2013). En

\footnotetext{
${ }^{4}$ Explica JuAnatey DoRAdo (2016) que la diferencia, a la luz de lo establecido por la jurisprudencia del TS y, por tanto, la relevancia penal de la desobediencia dependerá de la gravedad de los hechos valorada en atención a todas las circunstancias concretas del caso. En todo caso, la autora alude a diferentes manifestaciones del TS que ayudarían a observar tal diferencia. Entre ellas cita la STS 72/2002, de 21 de enero donde el tribunal establecía que "los criterios valorativos diversos que el buen sentido jurídico suministra, tales como la índole o contenido de la orden, el grado jerárquico del que dispone u ordena, la trascendencia del inatendimiento o pasividad del individuo, su actitud o modo de proceder, y, sobre todo (...) atendiendo a las circunstancias o accidentes de lugar, modo y tiempo e intencionalidad del agente". Igualmente menciona la STS $27 / 2013$, de 21 de junio donde se argumenta la diferencia por la "manifiesta y reiterada oposición al cumplimiento de la orden legítima emanada de la autoridad y los agentes, la grave actitud de rebeldía, la persistencia en la negativa... la contumaz y recalcitrante negativa a cumplir la orden"; así como la STS 463/2015, de 14 de julio donde se alude también a la importancia del bien jurídico que se pretenda proteger mediante la norma de conducta.
} 
consecuencia, si ésta es la razón de la intervención del Derecho penal debemos asumir también que la sanción penal de la desobediencia producirá un efecto disuasorio mayor que la infracción administrativa (MIRÓ LLINARES y BAUTISTA ORTUÑo, 2013), ya que, en caso contrario, no tendría justificación racional, cuanto menos desde una perspectiva de razón instrumental (PAREDES CASTAÑón, 2013; DíEZ RIPOLlÉs, 2013) la llamada al Derecho penal. Estas consecuencias de la intervención penal se dan precisamente por asumidas en la dogmática penal. Así, ÁLVAREZ GARCÍA (2013) que entiende que la tipificación de las desobediencias en el Código Penal como normas de conducta está revestida de legitimidad democrática al ser adoptadas por el Parlamento, también considera que esta legitimidad democrática está vinculada a la función de la prevención general negativa, es decir, a la necesidad de que el mensaje normativo como instrumento para la consecución del cumplimiento de las normas, sea lo suficientemente intimidatorio y poderoso para conseguir que las personas se abstengan de realizar determinadas conductas atentatorias contra el principio de autoridad.

Se parte y se deposita toda confianza, pues, en la función disuasoria de la pena (o sanción administrativa) asociada a la norma de conducta como medio para conseguir un cumplimiento normativo que se ha mostrado más necesario que nunca para la mitigación de los efectos individuales y sociales del SARS-COV-2. Pero tal presupuesto, que asume que la intervención penal tendrá efectos disuasorios y, en este caso, más efectos disuasorios que la infracción administrativa, es obviamente de naturaleza fáctica y, por tanto, susceptible de ser comprobado empíricamente. $\mathrm{Si}$, por lo menos hasta que la ciencia proporcione una vacuna que permita la inmunización a la mayoría de la población ${ }^{5}$, el mejor modo de prevenir el contagio en determinados momentos es el cumplimiento de la norma de confinamiento establecida por el Estado, comprobar empíricamente si la amenaza del castigo penal logra tal efecto preventivo no puede si no entenderse parte del proceso argumentativo sobre la justificación de la intervención del Derecho penal. Tiene razón ÁLVAREZ GARCíA (2013) cuando señala que, en las circunstancias en las que estábamos, el establecimiento de esta norma de conducta podría gozar de legitimidad democrática, y también la sanción a su infracción. Pero ello exige cuestionar previamente si el mensaje normativo basado en la intimidación, en la prevención general negativa y, por tanto, en la severidad y certeza del castigo, es lo que realmente está detrás del cumplimiento del confinamiento o si, por el contrario, el legislador y la doctrina penal tienen una confianza exagerada en dicho mensaje normativo, y en particular en la sanción penal, como medio de prevenir el incumplimiento.

Esta última idea, que se resumiría en la consideración de que la capacidad disuasoria y, por tanto, preventiva de la norma penal no está tan directamente relacionada con la severidad del castigo penal como el legislador suele creer, se ha venido evidenciando por medio de los estudios empíricos sobre el cumplimiento de las normas en distintos ámbitos normativos (MIRó LLINARES y BAUTISTA-ORTUÑo, 2013; GÓMEZ-BELlVís, 2019; GóMEZ-BELLVÍs y Miró LLINARES, 2020; Miró LLINARES y GÓMEZ BELLVís, 2020). Y, precisamente porque solo la conducta acorde con la norma es nuestra "bala de plata" o "fórmula mágica" contra el virus, adquiere sentido la investigación empírica sobre los factores asociados al cumplimiento de las normas. ¿Cómo vamos a depender, pues, de una estrategia normativa si no se mide empíricamente su eficacia?

\footnotetext{
${ }^{5}$ Tal y como dijo la coordinadora de respuesta frente al coronavirus de Estados Unidos, DeBorah BiRX, “There's no magic bullet. There's no magic vaccine or therapy. It's just behaviors". Recuperado de: https://www.hindustantimes.com/world-news/there-s-no-magic-bullet-covid-19-will-kill-100-000-to240-000-americans-say-white-house-experts/story-W32WupPsf7kXytSR4ZzmWI.html
} 
Pero también adquiere sentido propio a la luz del debate sobre la necesidad de ligar las reflexiones ético-normativas con los presupuestos empíricos que asumen o que se dan por sentados, como medio racional de justificación de la intervención del Estado en la libertad (Miró Llinares, 2017, 2018; PARedes Castañón, 2013; Díez Ripollés, 2013) ¿Cómo puede, si no, justificarse la expresión punitiva del Estado en este contexto tan característico cuando carecemos de toda certeza de que realmente ese punitivismo tiene el efecto que predica? En este sentido, necesitamos acercarnos a la realidad y examinar los efectos reales del mensaje penal para no caer en una suerte de "paradoja básica de la dogmática penal” definida por GARCíA AMADO (2019) como la pérdida de "congruencia práctica, congruencia externa (si así se puede decir), congruencia entre fines y medios" al fundamentar la pena en la prevención "ya que se desentiende grandemente del análisis de los efectos individuales y sociales de las sanciones” ( $\mathrm{p}$. 20).

Este es, por tanto, el objetivo general del presente trabajo de investigación: analizar, por un lado, la eficacia preventiva del modelo de la disuasión que se encuentra detrás de la sanción penal del incumplimiento del confinamiento, esto es, cómo influye o en qué medida motiva al cumplimiento el mensaje normativo intimidatorio; y, en segundo lugar, analizar la influencia de otros factores psicosociales y contextuales que podrían explicar qué es lo que influye en la decisión de infringir o no la norma y que, por tanto, se relacionan con el mensaje normativo. Para ello se tendrán en cuenta los principales enfoques que la literatura científico-social del cumplimiento normativo ha identificado como relevantes: tales como el enfoque de la influencia social y la legitimidad sustantiva y procedimental. Por último, también se tendrán en cuenta factores contextuales o ambientales que puedan estar afectando al cumplimiento del confinamiento, dada la excepcionalidad de la norma de conducta y las características ligadas a su cumplimiento.

\section{Justificación del enfoque del estudio: los factores asociados al cumplimiento normativo}

El por qué se cumplen las normas o cuáles son los factores asociados a dicho cumplimiento ha sido una pregunta de investigación presente durante décadas en la literatura científica de la Criminología, la Psicología Social, la Sociología, pero, también, quizás más de forma implícita que explícita, del Derecho Penal. Más allá del debate clásico sobre la justificación de la pena, y de la reactivación reciente de las teorías retributivas tanto en el ámbito anglosajón como en el continental (MOORE, 19876; PAWLICK, 2004, si bien con tintes de prevención general positiva no normativa), y en particular de las teorías expresivas de la pena bien en su forma deontológica (FEINBERG, 2011) o más consecuencialista (RoBinson 2012, KAHAN y UnsSBaum, 1996, más recientemente RODRíGUEZ HORCAJO, 2016), desde la perspectiva de la justificación instrumental de la conminación específica penal (HöRNLE, 2015) el entendimiento del Derecho penal como “orientado a las consecuencias" conlleva que tal intervención se justifique, en última instancia, en la capacidad de la norma de prevenir el incumplimiento o la realización de conductas socialmente disvaliosas. Es en este sentido que adquiere fuerza justificativa el modelo penal de la disuasión. Sin embargo, tal y como se analizará a continuación, la investigación empírica ha venido arrojando serias dudas sobre la eficacia de este modelo para la prevención de delitos, subrayando el alcance limitado de esta teoría y, en particular, el escaso papel que la severidad

\footnotetext{
${ }^{6}$ Sobre las aportaciones de este autor véase el magnífico homenaje a su obra en KESSLER, K.; MorSE, S.
} (2016). Legal, Moral, and Metaphysical Truths: The Philosophy of Michael S. Moore, Oxford University Press. 
desempeña en su potencial funcionalidad (MIRó LLINARES, 2017). Es por ello por lo que la literatura ha tratado de abordar otros enfoques y variables que podrían estar relacionados y explicar qué factores se encuentran detrás de la decisión de incumplir las normas penales, no solamente porque el conocimiento de éstos tenga un valor en sí mismo desde una perspectiva fenomenológica, sino porque tal conocimiento puede ser valioso para la toma de decisiones normativas informadas empíricamente. Entre dichos enfoques se encuentra el de la influencia social y el de la legitimidad tanto en un sentido sustantivo como procedimental, y que se detallan en los siguientes subepígrafes y se pondrán en relación con la literatura disponible sobre el cumplimiento del confinamiento y las medidas de distanciamiento social.

\subsection{El enfoque de la disuasión}

Uno de los enfoques quizá más estudiados en el ámbito del cumplimiento normativo sea el enfoque de la disuasión (General Theory Deterrence [BECKER, 1968] o Prevención General Negativa [BECCARIA, 1764/2011; FEUERBACH, 1989) y que tiene como objetivo analizar si la hipótesis que parece estar detrás de la criminalización de conductas en el ámbito penal tiene alguna eficacia en la motivación de las personas a cumplir. La hipótesis de la que se parte es muy sencilla a la vez que intuitiva (ALVIRA MARTín, 1984), y asimilada especialmente en Derecho Penal: las personas cumplirán con la norma dependiendo de cómo sea el mal con el que se amenaza, es decir, de las características del castigo. Y, éstas, son en su formulación clásica la severidad propia del castigo, la certeza o probabilidad de su imposición y la prontitud con la que el mismo se impone (BECCARIA, 1764/2011; BENTHAM 1789/2017; GARCía ÁlVAREZ, 2013). Estas tres características han sido analizadas detalladamente por la literatura científica llegando a varias conclusiones al respecto. En primer lugar, que estas características tienen un doble nivel: un nivel objetivo, referido a la severidad, certeza y prontitud real del castigo; y, un nivel subjetivo como la severidad, la certeza y la prontitud percibida por el sujeto que debe verse influenciado por las mismas (PATERnOSTER, 2010, 2018; Miró LlinARES y BAUTISTA ORTUÑo, 2013; APEL 2013); siendo precisamente la certeza y severidad de este segundo nivel, el percibido, las que tienen capacidad de influir en el comportamiento (MIRÓ LLINARES y BAUTISTA ORTUÑo, 2013; PATERNOSTER, 2018). En segundo lugar, que la certeza y severidad percibidas, principales características estudiadas, no tienen una especial influencia para motivar al cumplimiento o para explicar la comisión de delitos. Así, en el metaanálisis realizado por Pratt, Cullen, Blevins, Daigle y Yamara (2006) sobre el estado de la teoría de la disuasión se concluye que el tamaño del efecto medio entre el crimen y las variables de esta teoría son modestas e insignificantes, lo que sugiere que esta teoría tiene importantes limitaciones para explicar las conductas delictivas. Más concretamente y aplicando esta teoría en ámbitos normativos concretos se ha comprobado que este enfoque tiene poca relevancia en los modelos de cumplimiento o de prevención de conductas infractoras (por ejemplo, en el ámbito de la propiedad intelectual [Gómez-Bellvís, 2019; Gómez BellVís y Miró LLINARES, 2020; PÉrezDomínguez, Castro-Toledo y Miró-Llinares, 2019; DeCamp, 2009; Rando Casermeiro, 2019; BOSSLER, 2019], o de la emisión de mensajes en redes sociales [Miró LLINARES y GóMEz BELLVís, 2020; BAUTISTA OrtuÑo, 2017]; en el de la seguridad vial [Miró LlinARES y BAUTiSTA ORTUÑo, 2013]); o que, incluso puedan tener un efecto contrario a la hipótesis de partida (MIRÓ LLINARES y BAUTISTA ORTUÑO, 2013, donde los autores encuentran que respecto de la conducta de exceder los límites de la velocidad la severidad percibida estaba relacionada con un mayor incumplimiento). En tercer lugar, los anteriores hallazgos deben ser matizados en caso de que pueda entenderse que ninguna de las variables de la disuasión funciona para motivar el cumplimiento. Esto no es del todo así. Lo que la literatura indica es que en muchas ocasiones la 
severidad no despliega su eficacia a menos que haya un nivel de certeza suficientemente alto, es decir, a partir de ciertos niveles de certeza percibida la severidad puede jugar un papel en la disuasión (NAGin, 2013; Dusek y TRAXLER, 2020; PATERNOSTER, 2018).

En el ámbito del cumplimiento de las normas de confinamiento y distanciamiento social, este enfoque también ha sido puesto a prueba. Así, por ejemplo, RooI et al. (2020) emplean el enfoque de la disuasión con el objetivo de observar qué impacto tiene el mismo en que las personas decidan cumplir con las normas del confinamiento y distanciamiento social en una muestra de estadounidenses. De conformidad con sus resultados, no encontraron una relación entre las variables de la disuasión (severidad y certeza percibidas) con el cumplimiento de las normas de confinamiento y distanciamiento social. Tampoco lo hallaron KoOISTRA et al. (2020) en una muestra representativa de Reino Unido; ni tampoco KUIPER et al. (2020) en una muestra procedente de Países Bajos. Los tres estudios hipotetizan que la ineficacia de este modelo viene dada por la baja certeza percibida de la sanción de sus participantes, de tal modo que parece que los autores de estos estudios entienden que, si el nivel de certeza percibida de la sanción fuera superior al que es en realidad, la disuasión podría tener alguna influencia sobre el comportamiento. Estos estudios, como vemos, se centran en la medición del miedo a la sanción operativizado por medio de la severidad y certeza percibidas de la misma.

Ahora bien, otros estudios han hipotetizado que quizás sea otro miedo informal el que disuada a las personas de cumplir con las normas de distanciamiento social, es decir, la disuasión emocional. Es el caso del estudio de Graham, Cullen, Pickett, Jonson y Haner (2020). Así, señalan los autores que "rational choice/deterrence theory highlights the salience of perceived costs. In the current context, compliance with social distancing norms should be greater among those who perceive a higher certainty of death and who are afraid of being infected" (p. 2). En este sentido, en la operativización de estas variables señalaron que "because growing evidence that risk perceptions and deterrent emotions both influence criminal decision-making, we measured both. Perceived certainty is an indicator of respondents' perceived probability of death if they become infected with coronavirus [...] Personal fear is a mean index based on six items that asked how respondents were worried about various aspects of virus" (p. 14), incluyendo entre sus medidas el miedo personal al virus así como el miedo altruista entendido como la posibilidad de contagiar a terceros. De acuerdo con estas medidas, los autores encontraron que el miedo personal a las consecuencias del coronavirus estaba relacionado significativamente con las intenciones de cumplir con las recomendaciones de distanciamiento social, en el sentido de que, al margen de la certeza y severidad de las sanciones, aquellos participantes que tenían más miedo al contagio estaban más dispuestos a seguir las recomendaciones. Asimismo, HARPER, SATCHELL, Fido y LATZMAN (2020) encuentran que entre sus variables medidas (riesgo percibido de contraer el virus; miedo al virus; valores morales, orientación política y cambio en el comportamiento frente al coronavirus), el único predictor de cambios de conductas positivos como el distanciamiento social o las medidas de higiene, era el miedo de los participantes al virus. Por su parte, PLOHL y MusiL (2020) encontraron que la percepción del riesgo que supone para los participantes el virus era un predictor del cumplimiento de las medidas o pautas recomendadas para prevenir el contagio.

\subsection{El enfoque de la influencia social}

Tal y como exponían PRATT et al. (2006) en su metaanálisis, debido al modesto o insignificante efecto de las variables de la disuasión en el comportamiento delictivo, debe haber otras causas o factores detrás del (in)cumplimiento. En este sentido, KAHAN (1997) entendió que la decisión 
de cometer delitos no solamente está basada en la decisión racional e individual de evaluar los costes y los beneficios derivados de la infracción, sino que hay otras variables de carácter social que inciden en el cumplimiento. Concretamente, afirmaba el autor que:

Individuals don't decide to commit crimes in isolation; rather, their decisions interact with and reinforce each other in various ways. In particular, individuals are much more likely to commit crimes when they perceive that criminal activity is widespread. In that circumstance, they are likely to infer that the risk of being caught for a crime is low. They might also conclude that relatively little stigma or reputational cost attaches to being a criminal; indeed, if criminal behavior is common among their peers, they may even view such activity as status enhancing (p. 350).

Dicho de otro modo, la infracción o el incumplimiento de las normas puede depender más que de las variables de la disuasión (especialmente cuando no pueden garantizarse ciertos niveles aceptables de certeza), de la influencia social, es decir, de normas sociales que ofrecen, por un lado, la información al sujeto sobre qué es lo que hacen los demás y, por tanto, información sobre la conducta que es tolerable -norma descriptiva- y, por otro, de la percepción del juicio moral que emite la sociedad hacia el sujeto -norma prescriptiva- (CIALDINI, KALGREN y Reno, 1991; Miró LlinARES y BAUTISTA ORTUÑo, 20137), que en caso de ser negativa puede tener consecuencias adversas para el sujeto que decida incumplir (ej. la estigmatización). Tal y como sostiene RoBINSON (2012), "las personas sienten el vigor de una norma social como una fuerza externa que incide sobre ellos", y en consecuencia "las sanciones que se temen por la trasgresión de normas sociales generalmente se experimentan como provenientes de la comunidad y no dependen de la posibilidad de ser detenido y condenado" (p. 198). De conformidad con estas premisas teóricas, la evidencia empírica procedente especialmente de la Psicología Social que ha tratado de analizar en qué medida las normas sociales, es decir, la influencia social, se relaciona con la conducta normativa evidencian una importante relación (Cialdini et al., 2006; Cialdini y Goldstein, 2004; Goldstein, Cialdini y Griskevicious, 2008, Miró Llinares y Bautista Ortuño, 2013; Gómez Bellvís, 2019; Gaymard, 2009; entre muchos otros). Pero esta cuestión no solamente ha sido abordada por la Psicología Social, sino también por la Criminología. De hecho, teorías criminológicas como la del Aprendizaje social y la de la Asociación diferencial ponen el acento en la influencia de las relaciones del sujeto con otras personas en la comisión de conductas antisociales (REDONDO y GARRIDO, 2013).

En relación con el cumplimiento de las medidas de confinamiento y distanciamiento social, los estudios disponibles vienen a poner de relieve esta relación entre el cumplimiento y las normas sociales. En el estudio de RooI et al. (2020) en el que miden específicamente la norma descriptiva encuentran una fuerte relación con el cumplimiento, y sobre ello entienden que los estadounidenses cumplirán más si ven que los demás también cumplen con el distanciamiento social. Resultados convergentes encuentran KuIPER et al. (2020) sobre la muestra de Países Bajos y explican que, a su juicio, el Gobierno holandés ha sido inteligente al enfatizar las normas sociales y comunicar en las sucesivas ruedas de prensa que la mayoría de la gente está cumpliendo con las medidas, proporcionando así la información a la ciudadanía de que la conducta a seguir es, precisamente, respetar las normas de confinamiento. Asimismo, BOGG y

\footnotetext{
${ }^{7}$ Especialmente clarificadora es la definición que Miró LLINARES y BAUTISTA ORTUÑo (2013) realizan de las normas sociales. Los autores las definen como las "reglas y estándares compartidos por un grupo que sirven para guiar y/o restringir el comportamiento social de sus miembros, que surgen de la interacción social, que pueden estar más o menos explicitadas y cuya transgresión se penaliza con sanciones informales que aplica la sociedad, no el sistema legal” (p. 14).
} 
MiLAD (2020), en una muestra de 500 residentes en Estados Unidos mostraron que los sujetos que percibían que los demás apoyaban y animaban a seguir las guías de comportamiento frente al virus tenían más posibilidades de seguir dichas pautas. No obstante, KoIsTRA et al. (2020) no encuentran una relación entre la norma descriptiva y el cumplimiento de las medidas entre los residentes en Reino Unido. Por su parte, Nivette, Ribeadu, MurRay, Steinhoff, BeChtiger, HePp, SHANAHAN y EISNER (2020), midieron en su estudio sobre el incumplimiento de las medidas de salud pública entre jóvenes adultos si los participantes tenían amigos que realizaban conductas antisociales (Deviant peers and antisocial behavior) y encontraron una relación significativa entre tenerlos y el incumplimiento.

\subsection{El enfoque de la legitimidad sustantiva y procedimental}

Hasta aquí se ha puesto de relieve que la evidencia sugiere que la disuasión tiene un alcance limitado en la prevención de incumplimientos. Asimismo que, en la medida en que somos seres sociales también tomamos decisiones en relación con los demás, concretamente, teniendo en cuenta qué es lo que los demás hacen y cómo nos juzgan por hacer lo que hacemos en el ámbito de las normas sociales. Sin embargo, la literatura también ha puesto de manifiesto que el cumplimiento de una norma puede depender de algo más, en concreto del propio sistema de valores del individuo ligado a la idea de legitimidad sustantiva (MIRó LLINARES y BAUTISTA ORTUÑo, 2013; MiRó LLINARES, 2017). En este sentido, los estudios en determinados ámbitos normativos, por ejemplo, en la descarga ilegal de contenido, muestran que no solo la influencia social tiene un peso importante, sino también el propio juicio moral del sujeto con respecto de la conducta infractora (GómEZ-BeLLVís, 2019; GóMEZ-BELLVís y Miró LLINARES, 2020). Esto es, en última instancia, la creencia de si la conducta está bien o está mal, si es justa o injusta. En este sentido, si el individuo no cree que está haciendo algo malo o injusto, es decir, carece de los frenos morales para evitar la realización de una conducta, tendrá más probabilidades de llevarla a cabo.

En atención a lo anterior, la legitimidad sustantiva estaría integrada por el juicio moral que le merece a la persona en concreto la conducta y partiría de la hipótesis de que cuánto peor juzgue moralmente el sujeto una conducta menos la cometerá (TYLER, 1997; 2006). Por otro lado, también se ha indicado por parte de la literatura que la identificación de las intuiciones de justicia de la ciudadanía lega con las propias normas influye en que las personas cumplan con las normas en la medida en que, si dicha identificación se da, el modelo social de conducta legítimo queda reforzado, reforzando también así el cumplimiento de las personas como sujetos sociales (RoBinson, 2010; 2012; 2013; Miró LLINARES, 2017; GómEZ-BELLVís y MiRó LLINARES, 2019). En este sentido, los estudios de cumplimiento normativo muestran una relación entre la legitimidad sustantiva o alineación moral con la norma y su cumplimiento. En relación con el cumplimiento de las medidas de confinamiento y distanciamiento social, RooIJ et al. (2020) midieron la relación de alineamiento moral con la norma y encontraron que esta variable estaba relacionada con el cumplimiento y era predictor del mismo.

Pero la legitimidad a efectos de cumplimiento normativo no solo está compuesta por el propio sistema de valores y juicios morales de las personas, sino también por la relación e interacción de las personas con el propio sistema de justicia y sus autoridades, esto es, la legitimidad en un sentido procedimental. Quizás, el mayor exponente del estudio de la legitimidad procedimental sea TYLER (2006) que, con su célebre obra Why people obey the law, consagró la idea de que el cumplimiento de las normas depende de la legitimidad percibida de la ciudadanía sobre el sistema de justicia, sobre la legitimidad de la propia norma y de la aplicación que de ella hacen 
las autoridades legales, especialmente, los cuerpos y fuerzas de seguridad y que tiene como consecuencia que la ciudadanía desarrolle actitudes de obediencia porque cree que merecen ser obedecidas. Dicho de otro modo, la forma de socialización con el propio sistema legal es una variable que puede también afectar al cumplimiento normativo. Tal y como exponen TRINKNER y TYLER (2016) el proceso de socialización legal puede darse por medio de dos modelos diferentes: el primero, el coercitivo, que centra su atención en el castigo y el poder coercitivo de las autoridades que lo aplican y en una relación basada en la dominación; el segundo, el consensual que trata de fomentar la adquisición de valores positivos y de respeto en el trato, toma de decisiones justas, y el reconocimiento de los límites de la autoridad. El primero que es el basado en la estrategia de la disuasión anteriormente analizada ha sido especialmente criticado por Tyler y otros (TYLeR, 2003; 2011; FAgAN y TYLER, 2005; TRINKNER y TYLER, 2016) porque implica una relación agresiva que erosiona las relaciones comunitarias y el proceso de socialización legal (Miró LLINARES y CASTRO-TOLEDO, en prensa). El segundo, en cambio, tiene capacidad para promover confianza y legitimidad en el sistema y sus autoridades, y que dota al sistema de credibilidad y generan en la sociedad la actitud de obediencia a la ley y a las autoridades (REINER, 2010; JACKSON, 2018; CASTRO-TOLEDO, 2019), encontrándose evidencia empírica de esta relación (Miró Llinares y CASTRO-TOLEDo, en prensa; TYler 2017; NAGIN y TELEP, 2017).

Esta es, además, una de las variables tenidas en cuenta en los estudios de cumplimiento de las normas de conducta de confinamiento y distanciamiento social. NivETTE et al. (2020), analizaron la relación entre el cumplimiento y las actitudes hacia las autoridades como la legitimidad de la policía y la confianza en el Gobierno, y encontraron que las actitudes negativas hacia estas autoridades estaban asociadas con un incremento del incumplimiento de las medidas de distancia social, aunque no de las medidas de higiene. RooI et al. (2020) encontraron que la obediencia a las normas y autoridades basadas en el miedo a éstas últimas produce un efecto inverso, esto es, cuanto más miedo tienen los participantes a las autoridades que hacen cumplir las medidas, más se desobedecen.

\subsection{Otros factores: los factores ambientales o contextuales del cumplimiento del confinamiento como particularidad}

Que la norma que prescribe el confinamiento es de carácter excepcional y muy particular no cabe ninguna duda. Su carácter excepcional deviene porque la regla general es la libertad que, sin embargo, la totalidad de la ciudadanía ha visto limitada seriamente pese a que las razones de tales restricciones estén justificadas en atención a la situación tan excepcional que hemos vivido y seguimos viviendo como consecuencia de la pandemia. Sin embargo, también se ha puesto de manifiesto que no todas las personas tienen el mismo nivel de dificultad de soportar el confinamiento en atención a sus circunstancias particulares. De hecho, en diversos debates públicos se ha puesto de relieve que el confinamiento también ha mostrado desigualdades ${ }^{8}$. Supuestamente, no es lo mismo cumplir el confinamiento en un piso de 50 metros cuadrados que en un chalet de 200; que ni siquiera es lo mismo entre un piso de 50 metros cuadrados con

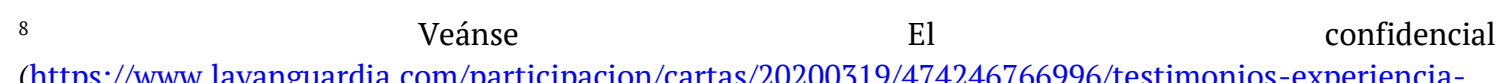
(https://www.lavanguardia.com/participacion/cartas/20200319/474246766996/testimonios-experiencia-
confinamiento-coronavirus-covid-19-minipiso.html); Público (https://www.publico.es/sociedad/confinamiento-viviendas-pequenas-cinco-personas-35-metros-

cuadrados-cinco-semanas-confinamiento.html); 20minutos (https://www.20minutos.es/noticia/4239855/0/pasar-confinamiento-metros-cuadrados-invivible/), entre muchos otros. 
balcón que sin él; que tampoco debe ser lo mismo un confinamiento en un piso de 50 metros cuadrados con hijos menores a cargo que sin ellos. En este sentido, es necesario tener en cuenta los factores ambientales y contextuales del cumplimiento con el objetivo de observar si tienen alguna incidencia. Del mismo modo, algunas características de los sujetos también se han mostrado en la literatura como factores que influyen en el cumplimiento. Es el caso, por ejemplo, de la ideología política donde podemos encontrar algunos resultados mixtos. Así, por ejemplo, mientras que RooI et al. (2020) no encontraron una relación entre la ideología política y el incumplimiento, sí lo encontraron Kushner, GADARINA, GOODMAn y PEPINSKY (2020) en el sentido de que los republicanos tenían menos probabilidades de llevar a cabo conductas recomendadas contra el coronavirus que los demócratas, así como que les preocupaba menos la pandemia y apoyaban más las políticas de restricción del comercio y de las fronteras. Asimismo, BROUARD, VASILOPOUlOS y BECHER (2020) hallaron que la ideología extremista está asociada con una reducción del apoyo a las recomendaciones de salud pública.

\subsection{Recapitulación}

En los apartados anteriores se ha tratado de analizar los distintos enfoques de cumplimiento que la literatura empírica ha relacionado con el mensaje normativo penal y su cumplimiento. En este sentido, se ha puesto en duda la hipótesis de la disuasión; se ha puesto en valor la relación de los factores sociales con la decisión de realizar una conducta y, también, del papel del sistema de valores del individuo con respecto a sus propios juicios morales y a sus creencias sobre el sistema de justicia y sus autoridades derivadas de la legitimidad procedimental. Sin embargo, también es cierto que la literatura disponible sobre la eficacia de cada modelo se ha analizado en contextos normativos y sociales tremendamente diferentes al actual, y requieren ser evaluados frente al cumplimiento del confinamiento por distintas razones. En primer lugar, no tenemos información en nuestro país sobre los efectos disuasorios del mensaje normativo penal en el contexto del estado de alarma, y si el alcance explicativo de la disuasión podría haber aumentado como consecuencia de los cambios en las variables, esencialmente, de la certeza percibida. Así, numerosos medios de comunicación se han hecho eco de un aumento de la vigilancia policial en las calles para evitar el incumplimiento ${ }^{9}$, lo cual unido a las sanciones administrativas y penales especialmente severas (bien en términos cuantitativos como los elevados importes de las sanciones administrativas, bien cualitativos con la intervención de la rama del ordenamiento jurídico más dura como es la del Derecho penal), puede haber desplegado un efecto motivador. Por otro lado, dado que la certeza de la imposición de la sanción puede haber aumentado, tendremos que determinar también si ante estos niveles de certeza la severidad despliega un efecto disuasorio. En este sentido, resulta necesario evaluar si la sanción de la infracción administrativa es suficientemente eficaz por sí misma para disuadir el incumplimiento del confinamiento o si, por el contrario, ante la falta de capacidad motivadora el aumento de la severidad en que consiste la intervención del Derecho penal por medio del delito de desobediencia previene el incumplimiento allá donde la infracción administrativa no puede. Además, la excepcionalidad de la situación permite salvar la posible crítica que podrían argüir autores como RoBinson (2012) acerca de que la norma que no es conocida por la ciudadanía no puede disuadir. En este sentido, no es descabellado pensar que

9 Como ejemplos, véase: https://www.elperiodico.com/es/sucesos-y-tribunales/20200406/policianacional-aumenta-vigilancia-noches-7918680; https://www.leonoticias.com/ponferrada/ponferradarefuerza-vigilancia-20200512112118-nt.html?ref=https\%3A\%2F\%2Fwww.google.com\%2F; https://www.lavanguardia.com/vida/20200407/48378997026/la-policia-aumenta-la-vigilancia-aldetectar-relajacion-en-el-confinamiento.html; 
cada uno de los ciudadanos ha conocido la obligación de permanecer confinado y las sanciones asociadas a su incumplimiento, especialmente teniendo en cuenta que los medios de comunicación han informado sobre ello de manera constante. En todo caso, podemos apelar a que esto es así si tenemos en cuenta algunos indicios o datos indirectos como podrían ser las tendencias de búsquedas en Google del término o expresión "multas estado de alarma”, y que como se puede observar en el Gráfico 1 adquirió su mayor volumen de búsqueda después de decretar el estado de alarma.

Gráfico 1. Gráfico del volumen búsquedas en Google sobre el concepto "multas estado de alarma" en los últimos 90 días.

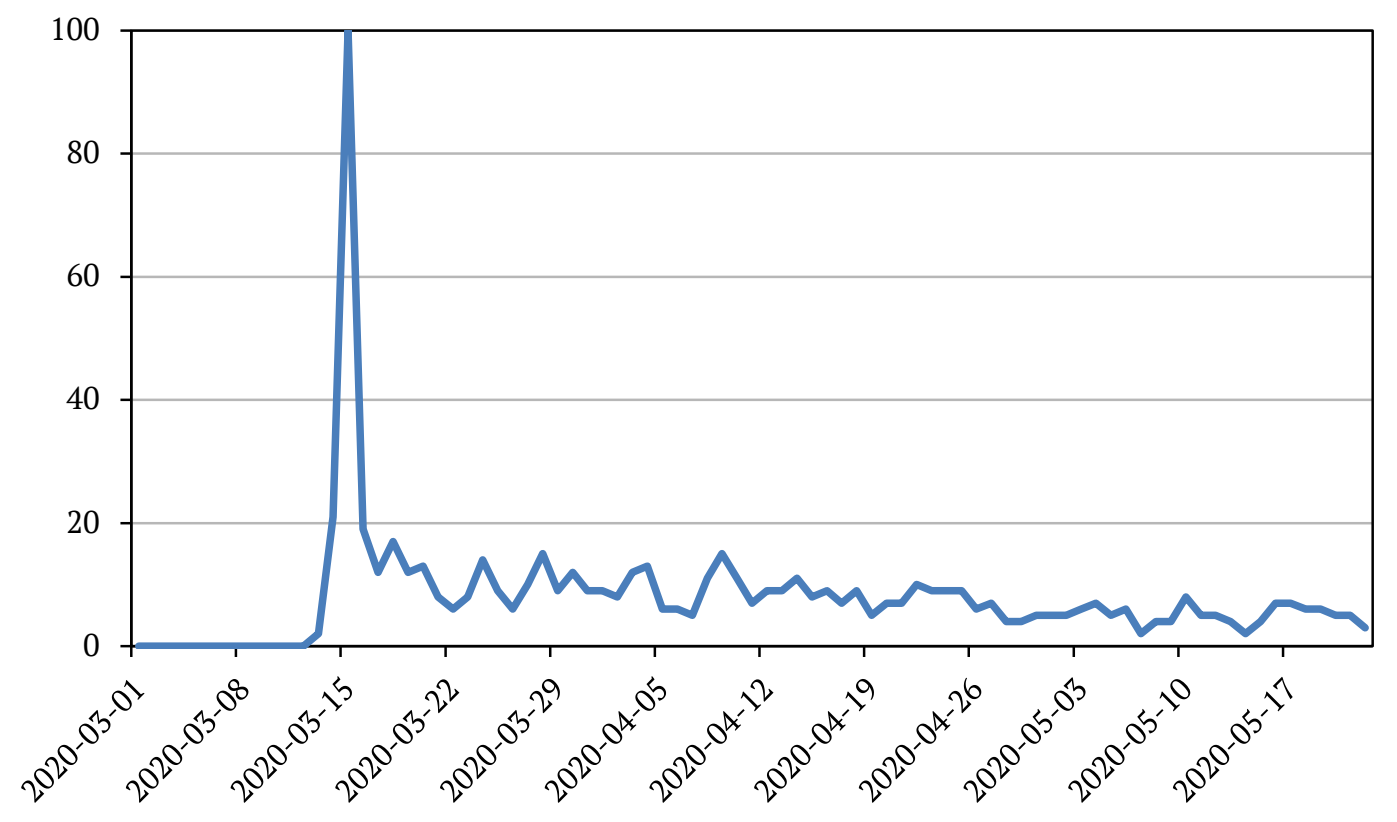

Fuente: Elaboración propia con datos de Google Trends

Por otro lado, podemos hipotetizar que la influencia social ha influido de algún modo en el cumplimiento de la medida, especialmente la que han ejercido los vecinos llamados "policía de balcón” 10 que recriminaban conductas supuestamente incumplidoras del confinamiento a viandantes, $\mathrm{y}$, asimismo, ligado a la idea de que no es adecuado infringir la única medida capaz de contener el virus, el sistema de valores que indica que esa infracción está moralmente mal. Asimismo, tampoco sería extraño pensar en una posible influencia del trato de la policía y de cómo de justas se han percibido las intervenciones de los cuerpos y fuerzas de seguridad del Estado. Especialmente teniendo en cuenta, por un lado, el importante número de propuestas de sanción y de detenciones realizadas, y, por otro, la calidad de las propias intervenciones (LÓPEZ RIBA, 2020).

En este sentido, el contexto del confinamiento constituye una oportunidad para, por un lado, analizar la influencia del mensaje normativo en el cumplimiento de las medidas del estado de alarma, y, por otro, evaluar si las características especiales del contexto normativo hacen variar

10 https://www.lavanguardia.com/local/barcelona/20200502/48894083154/policia-de-balcon-cuando-elvecino-se-erige-en-autoridad.html 
los resultados que la literatura empírica ha venido consolidando sobre cada uno de los enfoques.

\section{El estudio empírico}

\subsection{Objetivos e hipótesis}

El objetivo general del presente estudio es analizar los factores psicosociales y contextuales asociados al incumplimiento de la norma de confinamiento establecida en el artículo 7 del Real Decreto 463/2020. De dicho objetivo general se derivan los siguientes objetivos específicos:

O1. Evaluar la prevalencia de incumplimiento de la norma

O2. Analizar los factores procedentes de los enfoques propuestos (disuasión, influencia social, legitimidad sustantiva y procedimental, factores contextuales) y su relación con el incumplimiento del confinamiento.

O3. Elaborar un modelo matemático con los factores predictivos del incumplimiento

Para la consecución de los anteriores objetivos se plantean las siguientes hipótesis:

a. Desde el enfoque de la disuasión

H.1 a. A mayor severidad percibida mayor será el cumplimiento

H.1 b. A mayor certeza percibida mayor será el cumplimiento

H.1 c. A mayor miedo de contagiarse mayor será el cumplimiento

H.1 d. A mayor miedo de contagiar a los demás mayor será el cumplimiento

b. Desde el enfoque de la influencia social

H. 2 a. A mayor percepción de que la gente cumple el confinamiento mayor será el cumplimiento

H. 2 b. A mayor percepción de que la gente desaprobaría el incumplimiento mayor será el cumplimiento

c. Desde la perspectiva de la legitimidad sustantiva

H.3 a. Cuanto peor sea el juicio moral del incumplimiento mayor será el cumplimiento

H.3 b. Cuanto más grave sea percibido el incumplimiento mayor será el cumplimiento

d. Desde la perspectiva de la legitimidad procedimental

H. 4 a. A mayor actitud de obediencia a la ley mayor será el cumplimiento

H. 4 b. Cuanto mejor sea la percepción de la calidad de los agentes de la autoridad mayor será el cumplimiento

H. 4 c. Cuanto más se apoye la medida del confinamiento mayor será el cumplimiento

e. Desde la perspectiva de los factores ambientales o contextuales

H. 5 a. Cuantas más personas cohabiten mayor será el cumplimiento

H. 5 b. Cuantos más metros cuadrados tenga la vivienda mayor será el cumplimiento

H. 5 c. El acceso a espacios al aire libre en la vivienda influirá en un mayor cumplimiento 
H. 5 d. Tener hijos menores a cargo influirá en un mayor cumplimiento

H. 5 e. Cuando más tiempo se utilice Internet al día mayor será el cumplimiento

H. 5 f. Teletrabajar influirá en un mayor cumplimiento

\subsection{Muestra}

La muestra estuvo compuesta por 1312 participantes, de los cuales el 62,3\% ( $\mathrm{N}=818)$ eran mujeres y el 37,7\% (N=494) eran hombres, con una media de edad de 35,8 años (DT=13,7). De la muestra, un $70,7 \%$ tenía estudios universitarios, y de media la muestra se sitúa ideológicamente en el centro izquierda ( $M=3,38$; $D T=1,3$; en una escala del 1 al 7 , donde $1=$ extrema izquierda y $7=$ extrema derecha). En cuanto al estado civil, el 27,9\% estaba casado/a; el 4,8\% estaba divorciado/a-separado-a; el 3\% en una situación de pareja de hecho; el 31,1\% estaba soltero/a; el 31,7\% estaba soltero, pero con pareja y el 1,4\% era viudo/a. Por otro lado, un $97,1 \%$ de la muestra informaba no haber enfermado de coronavirus, mientras que un $54,7 \%$ informaba que sí que conocía a alguien que había enfermado. Toda la muestra residía en España.

\subsection{Variables y procedimiento}

Además de las anteriores variables sociodemográficas, el presente estudio ha medido como variable dependiente el incumplimiento de la medida de confinamiento establecida en el artículo 7 del RD 463/2020. Como variables independientes se han tenido en cuenta a) las variables del enfoque de la disuasión, tanto la severidad y certeza percibidas, como la disuasión procedente del miedo al contagio y también del miedo a contagiar; b) las variables del enfoque de la influencia social; c) variables de legitimidad sustantiva; d) variables de la legitimidad procedimental; y, e) por último variables contextuales. Tanto las variables, como su operativización y escalas de medición aparecen detalladas en el ANEXO 1. Para la consecución de los objetivos e hipótesis planteadas se consideró que el mejor diseño de investigación era uno de carácter no experimental en el que todos los participantes respondieran ante las mismas condiciones y al mismo instrumento de medición.

Para la elaboración del cuestionario se utilizó el sistema de encuestas gratuitas de Google. Los criterios de inclusión de la muestra fueron: 1) residir en España; 2) tener al menos 13 años, y 3) hablar español. El cuestionario fue administrado a través de distintas redes sociales y estuvo disponible desde el día 30/03/2020 hasta el 27/04/2020. En este sentido, el muestreo llevado a cabo es no probabilístico.

\section{Resultados}

\subsection{Estadísticos descriptivos}

a. Variable dependiente "incumplimiento"

Ante la pregunta de con qué frecuencia habían salido los participantes a la calle fuera de los casos permitidos o abusando de éstos desde que se decretara el estado de alarma el 14 de marzo, la mayoría de los participantes informaron que no incumplieron la norma de confinamiento ni abusaron de los casos en los que se permitía transitar en la vía pública. En este sentido, sólo el 15,2\% de la muestra informó haber incumplido el confinamiento, y de ese 
15,2\%, el 10,2\% informó que solo lo había incumplido de 1 a 3 veces. Esta información viene recogida en la tabla 1.

Tabla 1. Frecuencia de la variable "incumplimiento"

\begin{tabular}{lll}
\hline Frecuencia & $\mathrm{N}$ & $\%$ \\
\hline Ninguna vez & 1113 & 84,8 \\
De 1 a 3 veces & 141 & 10,7 \\
De 4 a 6 veces & 33 & 2,5 \\
De 7 a 9 veces & 13 & 1 \\
De 10 a 12 veces & 2 & 0,2 \\
De 13 a 15 veces & 3 & 0,2 \\
Más de 15 veces & 7 & 0,5 \\
\hline
\end{tabular}

Fuente: Elaboración propia

\section{b. $\quad$ Variables independientes}

Tabla 2. Resultados descriptivos de las variables independientes incluidas en el estudio

\begin{tabular}{|c|c|c|c|c|c|c|}
\hline \multicolumn{2}{|c|}{ Variables independientes del estudio } & Nivel & $\%$ & $M$ & $D T$ & Escala \\
\hline \multirow{4}{*}{$\begin{array}{l}\text { Disuasión formal e } \\
\text { informal }\end{array}$} & Certeza percibida & - & - & 5,12 & 3,13 & $0-10$ \\
\hline & Severidad percibida & \multicolumn{5}{|c|}{ Véase Gráfico 2} \\
\hline & Miedo a contagiarse & - & - & 5,49 & 2,7 & $0-10$ \\
\hline & Miedo a contagiar & - & - & 7,44 & 2,9 & $0-10$ \\
\hline \multirow[t]{2}{*}{ Influencia social } & Norma prescriptiva & - & - & 7,51 & 2,5 & $0-10$ \\
\hline & Norma descriptiva & - & - & 4,96 & 2,1 & $0-10$ \\
\hline \multirow{5}{*}{$\begin{array}{l}\text { Legitimidad } \\
\text { sustantiva }\end{array}$} & Juicio moral & - & - & 8,84 & 1,8 & $0-10$ \\
\hline & Gravedad percibida & - & - & 8,35 & 2 & $0-10$ \\
\hline & Vigilancia policial & Sí & $68,8 \%$ & - & - & Sí/No \\
\hline & $\begin{array}{l}\text { Haber sido parado } \\
\text { por la policía }\end{array}$ & Sí & $14 \%$ & - & - & $\begin{array}{l}\text { Ninguna vez } \\
1 \mathrm{vez}\end{array}$ \\
\hline & & & & & & 2 veces \\
\hline \multirow{6}{*}{$\begin{array}{l}\text { Legitimidad } \\
\text { procedimental }\end{array}$} & & & & & & 3 veces \\
\hline & & & & & & Más de 3 veces \\
\hline & $\begin{array}{l}\text { Actitud de } \\
\text { obediencia_global }\end{array}$ & - & - & 7,7 & 2,3 & $0-10$ \\
\hline & $\begin{array}{l}\text { Calificación } \\
\text { policía_global }\end{array}$ & - & - & 6,34 & 2,6 & $0-10$ \\
\hline & $\begin{array}{l}\text { Apoyo a la medida } \\
\text { del confinamiento }\end{array}$ & - & - & 9,14 & 1,7 & $0-10$ \\
\hline & Apoyo futuro & - & - & 8,4 & 2,2 & $0-10$ \\
\hline \multirow[t]{6}{*}{$\begin{array}{l}\text { Variables } \\
\text { ambientales }\end{array}$} & $\begin{array}{l}\text { Personas } \\
\text { cohabitantes }\end{array}$ & - & - & 2,96 & 1,1 & $1-10$ \\
\hline & Metros vivienda & \multicolumn{5}{|c|}{ Véase Gráfico 3} \\
\hline & Espacio al aire libre & \multicolumn{5}{|c|}{ Véase Gráfico 4} \\
\hline & Hijos menores & Sí & $23,9 \%$ & - & - & Sí/No \\
\hline & $\begin{array}{l}\text { Horas de uso al día } \\
\text { de internet }\end{array}$ & \multicolumn{5}{|c|}{ Véase Gráfico 5} \\
\hline & Teletrabajo & Sí & $42,4 \%$ & - & - & Sí/No \\
\hline
\end{tabular}

Fuente: Elaboración propia

Por lo que respecta al enfoque de la disuasión, tal y como podemos observar en la tabla 2 la certeza percibida de media es relativamente aceptable $(M=5,12 ; D T=3,3)$, mientras que la 
severidad percibida ofrece unos datos descriptivos de gran variabilidad en las sanciones económicas tal y como se muestra en el Gráfico 2. No obstante, la mayoría de la muestra entiende que la sanción máxima que podrían llegar a recibir es una multa, y de entre las cantidades ofrecidas destaca la de 601 a 1000 euros, siendo esta precisamente la multa más común impuesta a los ciudadanos por el mero incumplimiento del confinamiento, quizás porque los participantes estaban informados de las sanciones reales. En todo caso, a los efectos de la presente investigación, resulta muy destacable que el 78,3\% de la muestra entienda que la sanción máxima que podrían recibir por incumplir el confinamiento sea una multa económica, y solo $12,4 \%$ entienda que la misma podría llegar a la prisión. Esto es, la severidad percibida de la sanción por el incumplimiento no es la procedente de la rama del ordenamiento jurídico que puede imponer al ciudadano penas de prisión.

Gráfico 2. Descriptivo de la variable severidad percibida

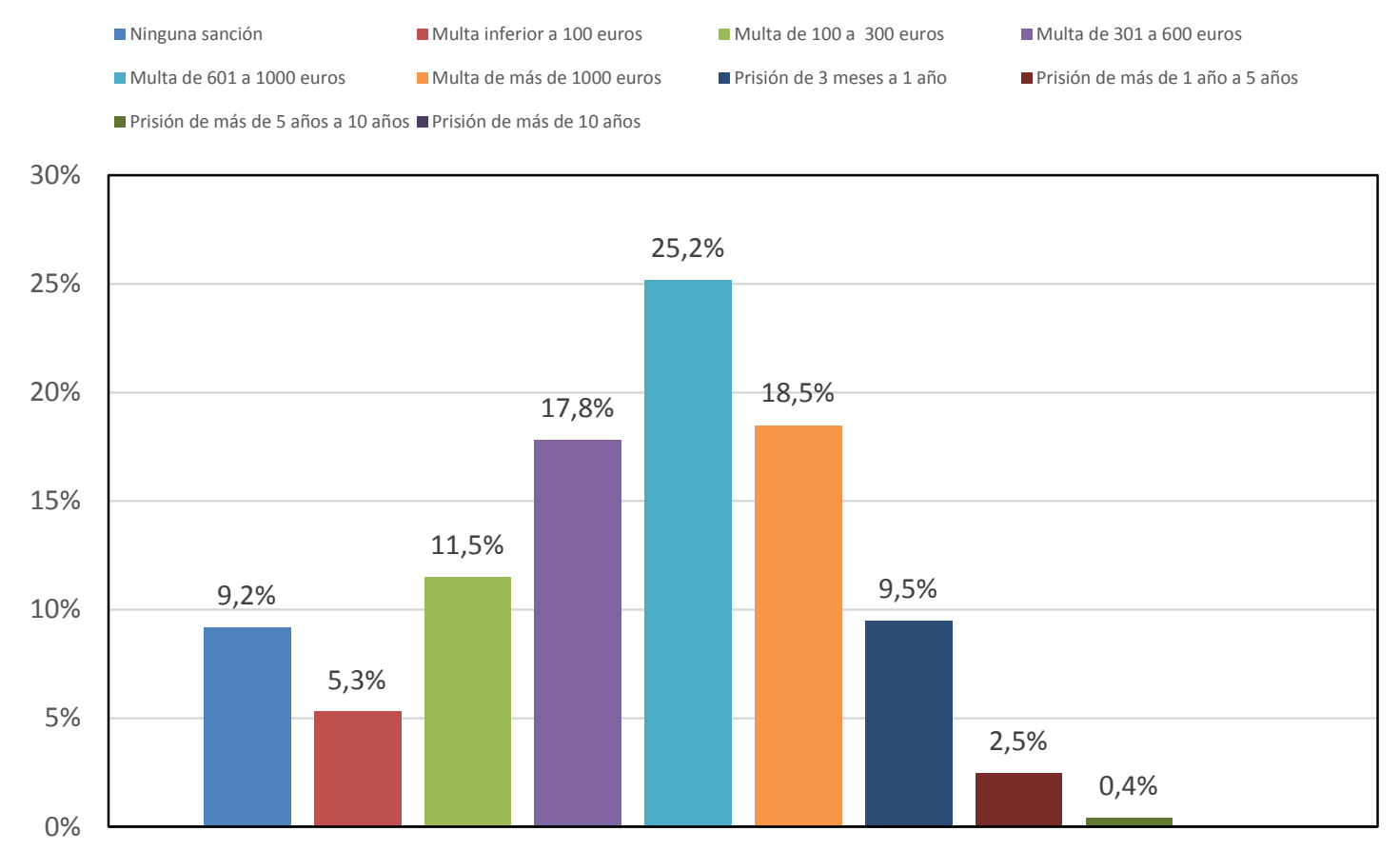

Fuente: Elaboración propia

Por otro lado, la muestra informa tener de media menos miedo a contagiarse que, sin embargo, miedo de contagiar a terceros donde la media es bastante alta $(M=7,44 ; D T=2,9)$. Respecto de la influencia social, la mayoría de la muestra cree que su grupo de referencia desaprobaría su comportamiento si incumplieran el confinamiento $(M=7,51 ; D T=2,5)$, siendo la media de la norma descriptiva, es decir, cuánta gente cree el sujeto que incumple el confinamiento, mucho más baja $(M=4,96 ; D T=2,1)$. Las medias más altas son las relativas a aquellas variables que están relacionadas con el sistema de valores del sujeto y, también, las relativas al apoyo de la medida del confinamiento. Así, de media la muestra cree que en términos morales la conducta de incumplir el confinamiento está muy mal $(M=8,44 ; D T=1,8)$, y, de forma coherente, la conducta infractora les parece muy grave $(M=8,35 ; D T=2)$. Asimismo, la muestra apoya ampliamente la medida de confinamiento y también lo haría respecto de una prórroga del mismo ( $M=9,14 ; D T=1,7$ y $M=8,4 ; D T=2,2$, respectivamente). 
Respecto de las variables de legitimidad procedimental, en primer lugar, se les preguntó si habían notado un aumento de la vigilancia policial en sus calles y barrios con una variable dicotómica (sí/no) y el 68,8\% de la muestra informaba que sí había notado dicho aumento. Por otro lado, se les preguntó si habían sido parados por la policía. En este caso un $86 \%$ de la muestra no había sido parado ninguna vez, un 9,7\% había sido parado una vez; un $3 \% 2$ veces; un $0,7 \% 3$ veces y un $0,6 \%$ más de 3 veces. Asimismo, también se les preguntó si habían sido multados por la policía con una variable dicotómica (sí/no) y solo el 0,6\% de la muestra informó haber sido multado. En cuanto al apoyo a la propia medida de confinamiento a la muestra les parecía que esta medida era totalmente adecuada $(M=9,14 ; D T=1,7)$ e igualmente les parecería adecuada una prórroga de dicho confinamiento $(M=8,4 ; D T=2,2)$. Toda esta información se encuentra disponible en la tabla 2 .

Por otro lado, respecto de la actitud de obediencia a la ley se operativizó mediante cuatro ítems extraídos de Tyler (2006), y adaptados al objeto de estudio. Estos ítems se encuentran detallados en la Tabla 3. Asimismo, se construyó una variable de actitud de obediencia global a partir de estos cuatro ítems, y para comprobar la fiabilidad interna del constructo se calculó el coeficiente de Alfa de Cronbach que arroja una fiabilidad alta $(\alpha=0,86)$. En consecuencia, de conformidad con este constructo, la media de actitud de obediencia la ley es de 7,7 ( $D T=2,3)$, tal y como podemos observar en la tabla 2.

Tabla 3. Ítems, escala y valor de Alfa de Cronbach del constructo de "actitud de obediencia a la ley"

\begin{tabular}{|c|c|c|c|}
\hline Ítems & Operativización & Escala & $\alpha$ de Cronbach \\
\hline 1 & $\begin{array}{l}\text { Las personas deben obedecer las obligaciones } \\
\text { impuestas durante el Estado de alarma, incluso } \\
\text { si va en contra de lo que creen que es correcto }\end{array}$ & & \\
\hline 2 & $\begin{array}{l}\text { Siempre trato de seguir las obligaciones del } \\
\text { Estado de alarma, incluso si creo que no son } \\
\text { correctas }\end{array}$ & $0=$ Totalmente & \\
\hline 3 & $\begin{array}{l}\text { Desobedecer el Estado de alarma nunca está } \\
\text { justificado }\end{array}$ & 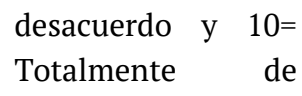 & $\alpha=0,86$ \\
\hline 4 & $\begin{array}{l}\text { Si una persona sale a la calle y un policía le dice } \\
\text { que se identifique o que se detenga, debe } \\
\text { detenerse e identificarse, aunque crea que lo } \\
\text { que está haciendo es totalmente legal }\end{array}$ & acuerdo & \\
\hline
\end{tabular}

Fuente: Elaboración propia

Se emplearon también 6 ítems para medir la calificación de los agentes de seguridad basada en una revisión de la escala empleada por Medina (2003) descritos, asimismo, en la tabla 4. Al igual que en el caso de la actitud de obediencia a la ley, se construyó una variable de actitud de calificación de los agentes de seguridad global a partir de estos seis ítems, y para comprobar la fiabilidad interna del constructo se calculó el coeficiente de Alfa de Cronbach que arroja también una fiabilidad alta $(\alpha=0,96)$. Así, tal y como se observa en la tabla 2 la calificación global de los agentes de la autoridad durante del estado de alarma es de media de 6,34 $(D T=2,6)$, indicando que pese a que no se califica mal a los agentes de seguridad tampoco se les considera del todo adecuados. 
Tabla 4. Ítems, escala y valor de Alfa de Cronbach del constructo de "calificación de los agentes de seguridad"

\begin{tabular}{llllll}
\hline Ítem & Operativización & Escala & & $\alpha$ de Cronbach \\
\hline 1 & Son profesionales y competentes & & & & \\
2 & Son respetuosos con el trato a los ciudadanos & & & \\
3 & Son honestos & & & & \\
4 & Son eficaces en la persecución de las & $0=$ Totalmente en & \\
& infracciones estos días & & desacuerdo y & $10=$ & $\alpha=0,96$ \\
5 & Son imparciales en sus actuaciones & & Totalmente & de & \\
6 & Son respetuosos con los derechos de los & acuerdo & & \\
& ciudadanos estos días & & & & \\
\hline
\end{tabular}

Fuente: Elaboración propia

Finalmente, respecto de las variables contextuales del cumplimiento evaluadas la muestra ha convivido durante el confinamiento con una media de 2 personas. Tal y como se observa en el Gráfico 3, mientras que solo el 8,1\% de la muestra ha pasado el confinamiento en una vivienda no superior a 50 metros cuadrados, el $22,4 \%$ lo ha pasado en una vivienda entre 51 y 75 metros cuadrados, el 34,1\% en una de entre 76 y 100 metros cuadrados, el 16,5\% en una de entre 101 y 120 metros cuadrados, y el $18,9 \%$ lo ha pasado en una vivienda de más de 120 metros cuadrados.

Gráfico 3. Descriptivo de los metros cuadrados de la vivienda

- Menos de $25 \mathrm{~m} 2$ Entre 25 y $50 \mathrm{~m} 2$ Entre 51 y $75 \mathrm{~m} 2$ Entre 76 y $100 \mathrm{~m} 2$ Entre 101 y 120 m2 Más de $120 \mathrm{~m} 2$

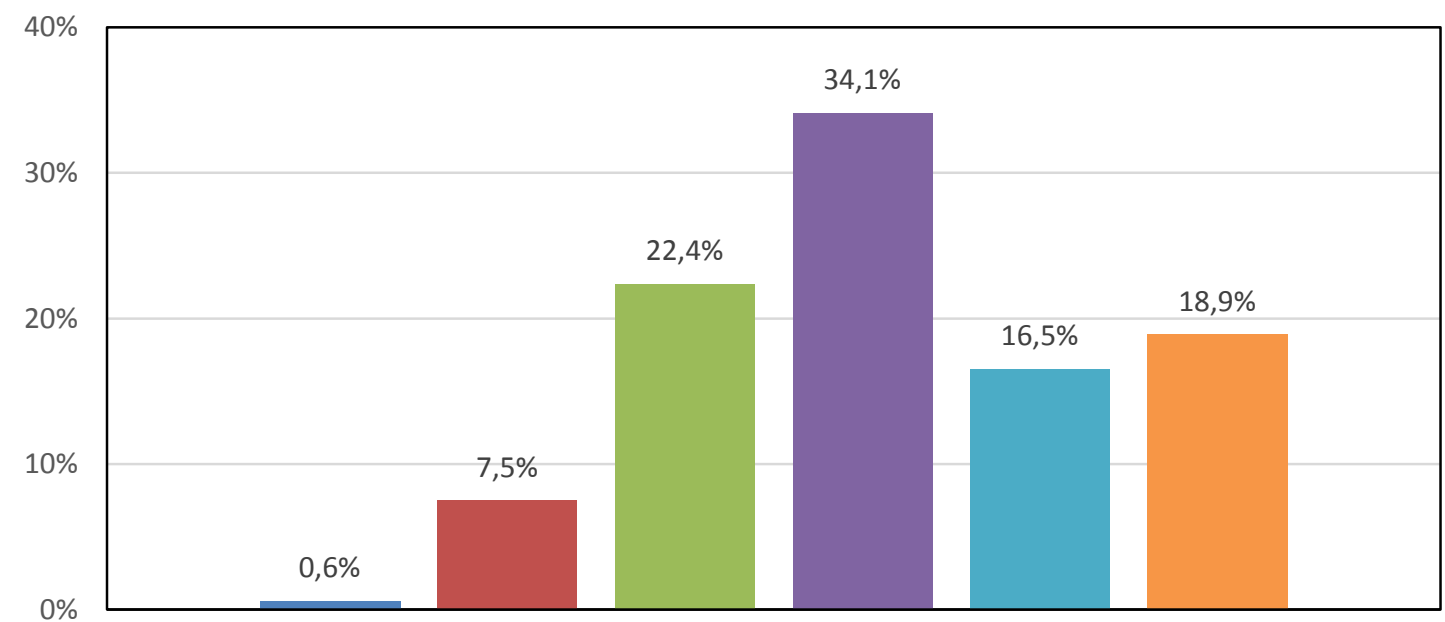

Fuente: Elaboración propia

Respecto de la disponibilidad de espacios al aire libre en la vivienda en la que se ha llevado a cabo el confinamiento, el $23,6 \%$ de la muestra informa de que no tiene ningún espacio al aire libre, mientras que el más del 55\% dispone o de balcón o de terraza, y solo el 16,9\% dispone de jardín, tal y como se detalla en el Gráfico 4. 
Gráfico 4. Descriptivo de los espacios al aire libre disponibles en las viviendas

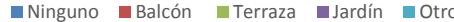

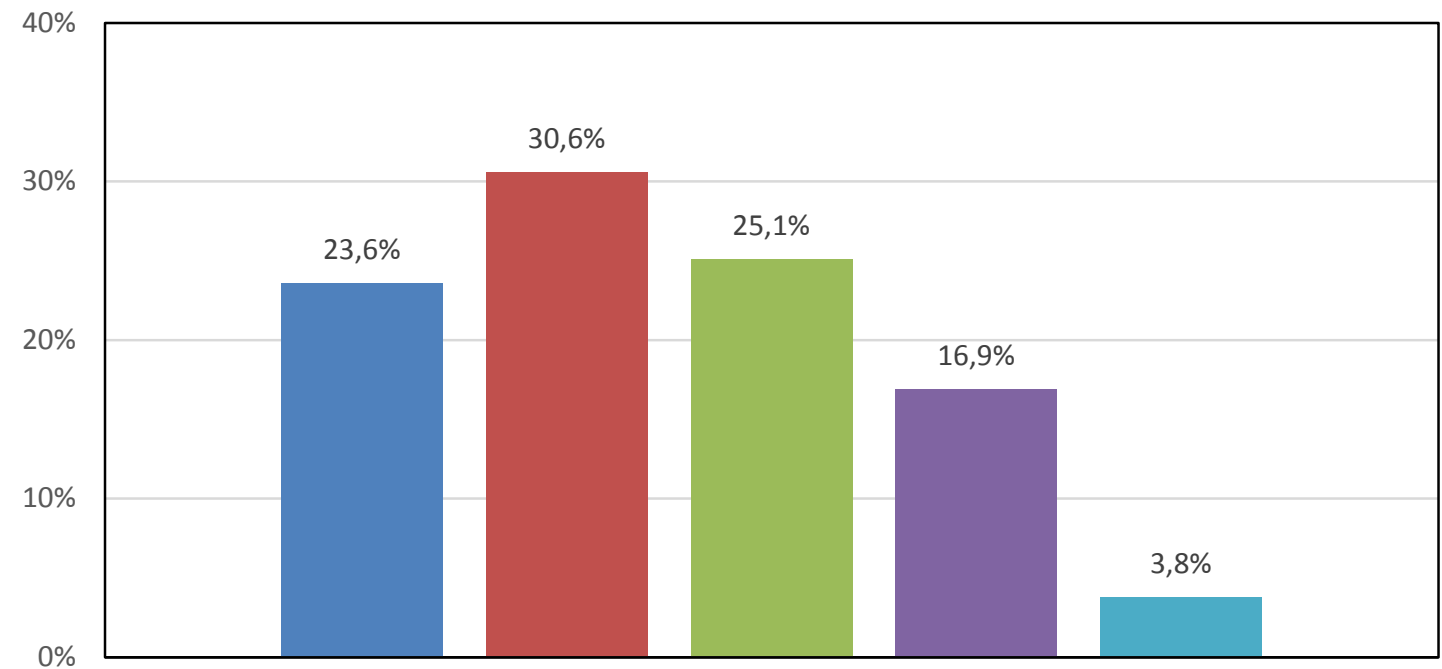

Fuente: Elaboración propia

Por otro lado, solo el 23,9\% de la muestra informa tener hijos menores a cargo.

Asimismo, y respecto de las horas de uso al día de Internet durante el confinamiento, el 80\% de la muestra hace uso de Internet entre 5 y más de 12 horas al día, tal y como se puede observar en el Gráfico 5. Por último, cabe mencionar que el $42,4 \%$ de la muestra se encontraba teletrabajando.

Gráfico 5. Descriptivo de las horas de uso de Internet al día

- 0 horas Entre 1 y 2 horas Entre 3 y 4 horas Entre 5 y 6 horas Entre 7 y 8 horas Entre 9 y 10 horas Entre 11 y 12 horas Más de 12 horas

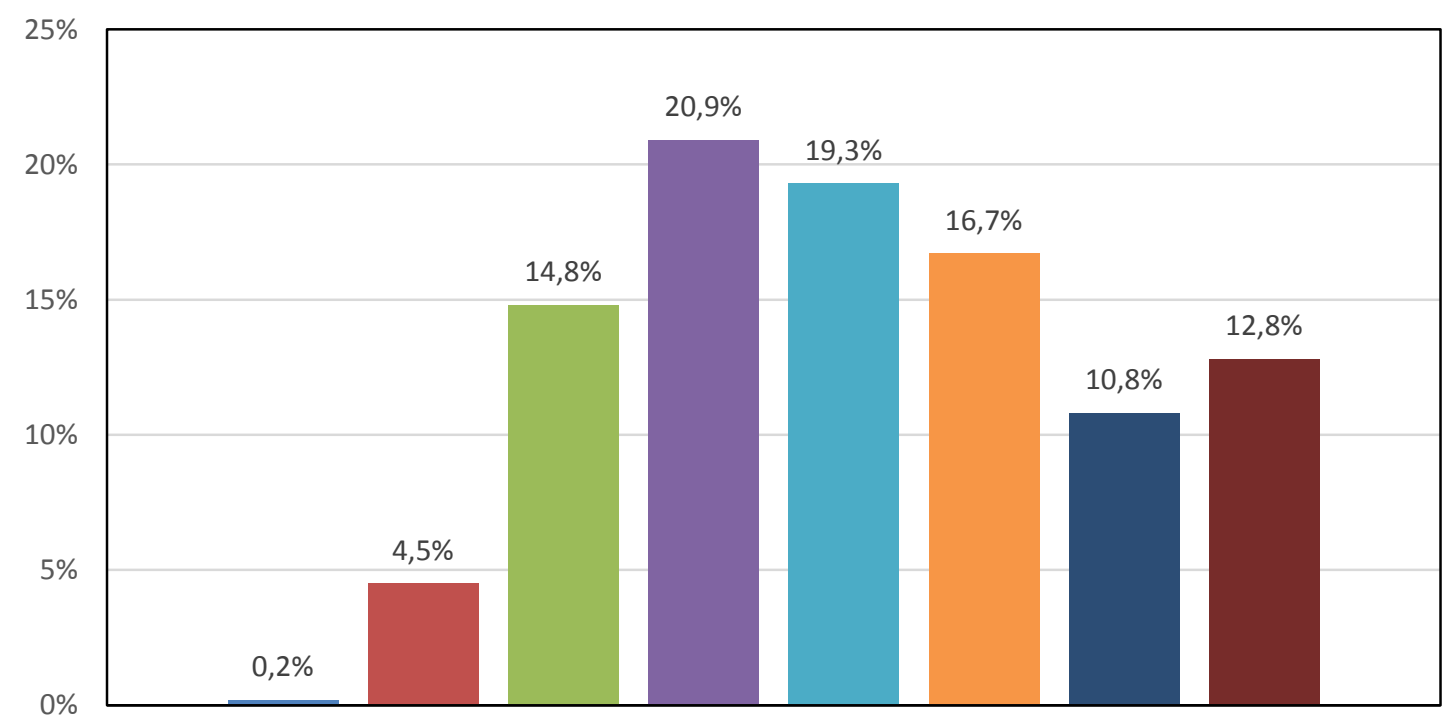

Fuente: Elaboración propia 


\subsection{Correlaciones bivariadas}

Una vez realizados los análisis descriptivos de las variables se procedió a realizar un análisis bivariante con todas las variables medidas en el presente estudio. Las correlaciones que se aplicaron atendiendo al tipo de variables comparadas (véase tabla 5).

Tabla 5. Correlaciones entre la variable incumplimiento y las variables independientes

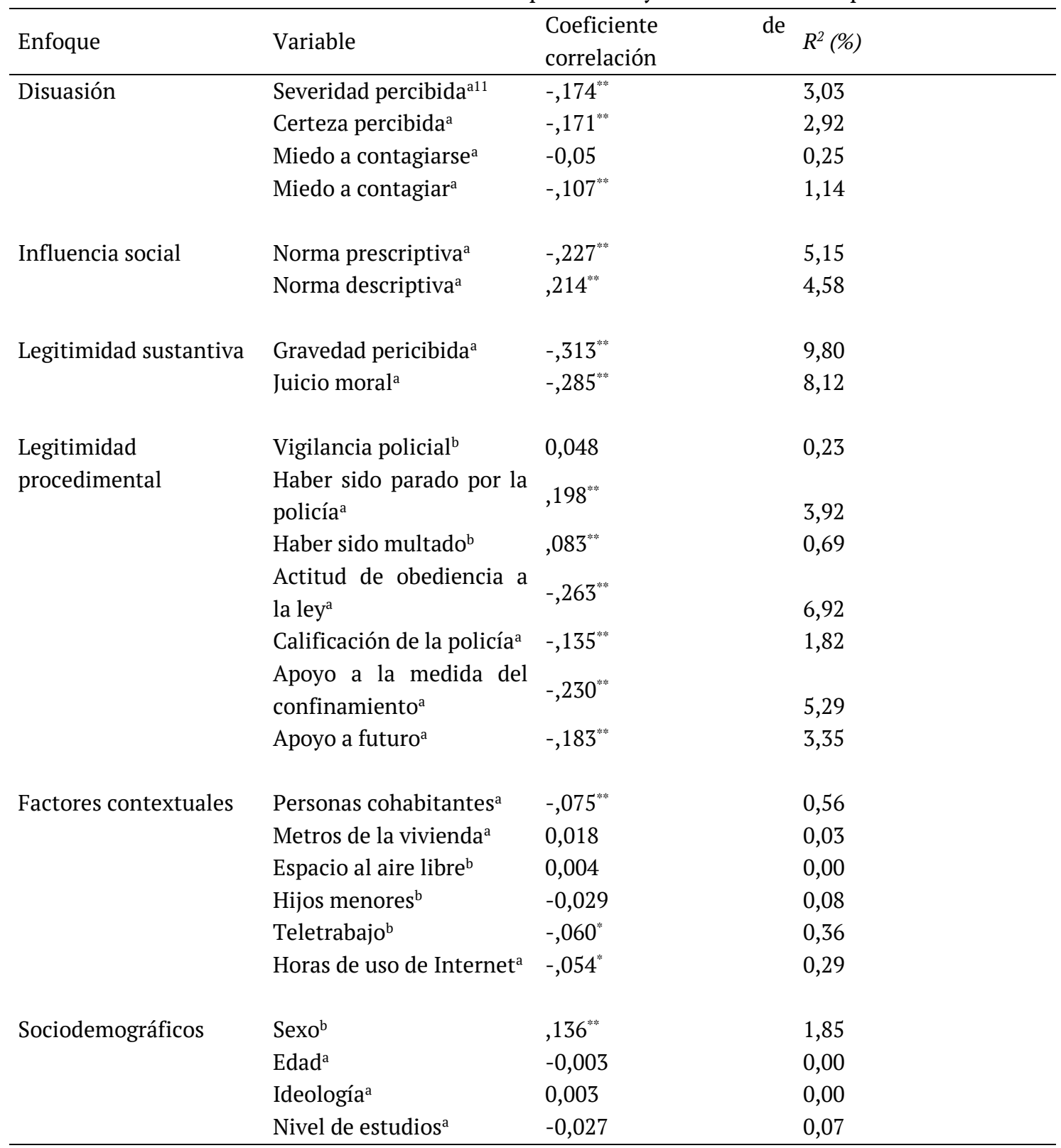

**. La correlación es significativa al nivel 0,01 (bilateral); *. La correlación es significativa al nivel 0,05 (bilateral); a. Correlaciones de Spearman; $b$. Correlaciones biseriales puntuales

\footnotetext{
${ }^{11}$ Con el objeto de profundizar sobre esta relación, se realizó un análisis de varianza de una vía (ANOVA) entre los participantes para comparar el efecto de la severidad percibida en el incumplimiento del confinamiento en condiciones de "no sanción", "sanción administrativa" y "pena de prisión". La prueba indica que existe un efecto significativo de la severidad percibida en el incumplimiento $(F(2,1331)=$ $8,503, \mathrm{p}<, 001)$. No obstante, tras aplicar la prueba post-hoc Tukey, la diferencia entre los grupos "sanción administrativa" y "pena de prisión" no es estadísticamente significativa $(\mathrm{p}=, 081)$.
} 
Como se puede observar, no existe una relación de dependencia entre el incumplimiento y las variables "miedo a contagiarse"; "vigilancia policial”; la edad; la ideología política, el nivel de estudios; los metros de la vivienda; el disponer de espacios al aire libre en la vivienda y el número de hijos menores a cargo. En consecuencia, las hipótesis H.1 c. A mayor miedo de contagiarse mayor será el cumplimiento; H. 5 b. Cuantos más metros cuadrados tenga la vivienda mayor será el cumplimiento; H. 5 c. El acceso a espacios al aire libre en la vivienda influirá en un mayor cumplimiento; $y$, H. 5 d. Tener hijos menores influirá en el cumplimiento, no pueden aceptarse.

Por lo que se refiere a las variables de la disuasión, podemos observar que la relación entre el incumplimiento y la severidad y certeza percibidas es negativa y estadísticamente significativa $\left(r_{s}=-, 174 ; p<, 01 ; r_{s}=-, 171 ; p<, 01\right)$. Esto es, cuanto menor es la severidad y la certeza percibidas mayor es el incumplimiento. En este caso, las hipótesis relacionadas con la disuasión de las sanciones (H.1 a. A mayor severidad percibida mayor será el cumplimiento; H.1 b. A mayor certeza percibida mayor será el cumplimiento) se aceptan. Asimismo, también existe una relación negativa y estadísticamente significativa entre el miedo a contagiar y el incumplimiento, por lo tanto, a menor miedo de contagiar a alguien mayor es el incumplimiento $\left(r_{s}=-, 107 ; p<0,01\right)$, por lo que también se acepta la hipótesis H.1 d. A mayor miedo de contagiar a los demás mayor será el cumplimiento. Ahora bien, se ha de tener en cuenta que las correlaciones negativas que oscilan entre los valores $-0,01$ a $-0,19$ se consideran correlaciones muy bajas. Esto también puede observarse con los valores de $R^{2}(\%)$.

Si atendemos a las relaciones entre la influencia social y el incumplimiento, podemos observar que cuanto menos crea el sujeto que la gente de su entorno desaprobaría su incumplimiento mayor es el incumplimiento $\left(r_{s}=-, 227 ; p<, 0,01\right)$; y cuanta más gente crea el sujeto que incumple mayor será el incumplimiento $\left(r_{s}=, 214 ; p<0,01\right)$. Se aceptan pues, las hipótesis planteadas en torno a la influencia social y el incumplimiento. Estas son: H. 2 a. A mayor percepción de que la gente cumple el confinamiento mayor será el cumplimiento; y, H.2 b. A mayor percepción de que la gente desaprobaría el incumplimiento mayor será el cumplimiento. En este caso, las correlaciones se consideran bajas.

Las relaciones más fuertes se producen entre las variables de legitimidad sustantiva y el apoyo a la medida del confinamiento. Así, a menor gravedad percibida del incumplimiento mayor será este $\left(r_{s}=-, 313 ; p<, 01\right)$; asimismo, cuanto mejor se juzgue moralmente la conducta mayor incumplimiento $\left(r_{s}=-, 285 ; p<, 01\right)$; así como, encontramos una relación significativa entre no apoyar la medida de confinamiento y el incumplimiento $\left(r_{s}=-, 230 ; p<, 01\right)$. Esta relación nos permite aceptar las hipótesis planteadas en torno a la legitimidad sustantiva (H.3 a. Cuanto peor sea el juicio moral del incumplimiento mayor será el cumplimiento; y, H.3 b. Cuanto más grave sea percibido el incumplimiento mayor será el cumplimiento). Si bien y al igual que en los casos anteriores, los valores de las correlaciones obtenidos se consideran bajos.

En lo que se refiere a las relaciones procedentes de las variables de la legitimidad procedimental, se observa que cuanto más se haya sido parado por la policía mayor es el incumplimiento $\left(r_{s}=, 198 ; p<0.01\right)$. Este dato puede resultar a primera vista contradictorio, pero puede hipotetizarse que aquellos que han incumplido más y, por tanto, han salido más a la calle, habrán tenido más probabilidades de ser parados por la policía como consecuencia de dicho incumplimiento. Haber sido multado también se relaciona con el incumplimiento, entendiendo dicha relación en la misma dirección que en el caso anterior $\left(r_{b p}=, 083 ; p<, 01\right)$. Respecto de la actitud de obediencia, encontramos una relación negativa y significativa $\left(r_{s}=-\right.$ 
,263; $p<, 01)$. Esto es, a peor actitud de obediencia mayor será el incumplimiento. Por otro lado, también se observa una relación negativa entre la calificación de los agentes de la autoridad y el incumplimiento $\left(r_{s}=-, 135 ; p<, 01\right)$. Se aceptan, en consecuencia, las H. 4 a. A mayor actitud de obediencia la ley mayor será el cumplimiento; y, H. 4 b. Cuanto mejor sea la percepción de la calidad de los agentes de la autoridad mayor será el cumplimiento, con las cautelas acerca de los valores bajos de correlación.

Respecto de las variables contextuales se encuentra que son las variables con una relación significativa menor, y, de hecho, los valores de las correlaciones se consideran muy bajos. Así, a menor número de personas que convivan en el domicilio mayor será el incumplimiento $\left(r_{s}=-\right.$ $, 075 ; p<, 01)$; tener hijos a cargo está relacionado con un menor incumplimiento $\left(r_{s}=-, 079 ; p<\right.$ $, 01)$; no teletrabajar se relaciona con el incumplimiento $\left(r_{b p}=-, 060 ; p<, 05\right)$, y, a menor número de horas de uso al día de Internet mayor es el incumplimiento $\left(r_{s}=-, 0.54 ; p<, 05\right)$. En este sentido, dada la débil relación solo podemos aceptar parcialmente las hipótesis H. 5 a. Cuantas más personas cohabiten mayor será el cumplimiento; H. 5 e. Cuando más tiempo se utilice Internet al día mayor será el cumplimiento; H. 5 f. Teletrabajar influirá en un mayor cumplimiento.

Por último, si atendemos a la relación del incumplimiento con las variables sociodemográficas, podemos observar en la tabla 5 que solo correlaciona significativamente el sexo $\left(r_{b p}=, 136 ; p<\right.$ ,01), de modo que ser mujer está relacionado con el incumplimiento. Sin embargo, esto último debe interpretarse con prudencia dado que puede deberse a la mayor prevalencia de mujeres en la muestra.

\subsection{Modelización matemática del incumplimiento}

Tras examinar los resultados del análisis bivariante y para la consecución de los objetivos específicos planteados en esta investigación, se procedió a la modelización del incumplimiento. Para ello, se utilizó una regresión logística binaria a la que se le aplicó el método hacia delante (condicional) de introducción de variables. Tras 5 pasos $^{12}$, las variables gravedad, certeza, norma descriptiva, actitud de obediencia a la ley y haber sido parado por la policía mostraron tener un efecto significativo sobre el incumplimiento del confinamiento $\left(\chi^{2}(5)=362,891, p<\right.$ $0,000)$. El modelo explica el $42,1 \%$ de la varianza en la muestra recogida ( $\mathrm{R}^{2}$ de Nagelkerke) y clasifica el $86,5 \%$ de los casos correctamente. La sensibilidad del modelo es del 33,5\% y la especificidad del 96\%. Los resultados muestran, por un lado, que por cada unidad que incrementan las variables gravedad, certeza y actitud de obediencia a la ley, la probabilidad de incumplir se reduce a 0,61 (38\%), 0,8 (44,4\%) y $0,8(44,4 \%)$ veces respectivamente. Por otro lado, el modelo también muestra que por cada unidad de incremento en las variables norma descriptiva y "haber sido parado por la policía”, las probabilidades de incumplir son de 1,7 $(62,9 \%)$ y $2(66,6 \%)$ veces más respectivamente. Toda esta información viene recogida en la tabla 6.

\footnotetext{
${ }^{12}$ Tal y como se describe en el ANEXO 2, el método hacia delante de introducción de variables aplicado calculó hasta 10 modelos distintos (10 pasos). No obstante, y pese a la significación de todas las 10 pruebas ómnibus de coeficientes del modelo, las pruebas Hosmer-Lemeshow relativas al modelo 6 en adelante muestran valores significativos que nos impiden rechazar la hipótesis nula de igualdad entre el modelo observado y el esperado, comprometiendo el ajuste del modelo.
} 
Tabla 6. Resultados de la regresión logística binaria del incumplimiento

\begin{tabular}{lllllll}
\hline & & & & & \multicolumn{2}{c}{ 95\% C.I. para O.R } \\
\hline & $B$ & ET $(B)$ & Wald* & O.R & Inferior & Superior \\
\cline { 2 - 7 } Gravedad de la conducta & $-0,489$ & 0,047 & 107,643 & 0,613 & 0,559 & 0,673 \\
Certeza percibida & $-0,215$ & 0,032 & 46,066 & 0,806 & 0,758 & 0,858 \\
Norma descriptiva & 0,546 & 0,053 & 105,838 & 1,725 & 1,555 & 1,914 \\
Actitud de obediencia & $-0,204$ & 0,036 & 31,541 & 0,815 & 0,759 & 0,875 \\
Haber sido parado por la policía & 0,728 & 0,127 & 33,076 & 2,072 & 1,616 & 2,656 \\
Constante & 1,278 & 0,399 & 10,264 & 3,59 & & \\
\hline
\end{tabular}

* $p<0,001$ en todas las variables.

Omnibus $\chi^{2}(5)=362,891, p<0,000$; Hosmer-Lemeshow. $\chi^{2}(8)=14,834, p=0,062$

$R^{2}=0,241$ (Cox y Snell), 0,421 (Nagelkerke).

\section{Discusión y conclusiones}

El presente trabajo de investigación tiene como objeto analizar la prevalencia de incumplimiento del confinamiento en el estado de alarma y determinar qué factores psicosociales y contextuales están asociados al mismo. El objetivo es discutir los presupuestos de la disuasión tradicionalmente admitidos por el legislador y, particularmente, comprobar empíricamente la relevancia de la severidad del castigo en el cumplimiento normativo. Tal y como se ha reflexionado al inicio de este trabajo, que el incumplimiento o la desobediencia pueda castigarse además de por vía administrativa por medio del Derecho penal debe poder justificarse, por un lado, en un mayor desvalor y gravedad de la conducta y, por otro, en un poder disuasorio que no haya podido ser capaz de desplegar la sanción administrativa. Esto, como se ha argumentado, es lo que justificaría, a nivel de razón instrumental, esta criminalización del incumplimiento ya que, de otra manera, si la sanción administrativa puede por sí misma prevenir las conductas infractoras, la injerencia de un Derecho penal basado en el principio de intervención mínima no estaría justificada (ALONSO RIMO, 2020).

El estudio muestra, en primer lugar, un bajo incumplimiento de la norma evaluada. Concretamente solo un 15\% informa haber incumplido el confinamiento durante el estado de alarma. Resultados similares encontraron el Grupo de Investigación "Democracy Elections \& Citizenship", que ante la pregunta a los participantes de si habían salido a la calle, aunque no fuese necesario, solo el 13\% informaba que sí lo había hecho ${ }^{13}$. Asimismo, RooIj et al. (2020), aunque evaluó el cumplimiento de forma distinta, encontró que la mayoría de la muestra de estadounidenses cumplía con las medidas de distanciamiento social evaluadas. También encontraron bajas frecuencias de incumplimiento NIVETTE et al. (2020); KUIPER et al. (2020); y KOOISTRA et al. (2020).

En relación con los factores de cumplimiento normativo que la literatura empírica ha mostrado previamente que se relacionan con la toma de decisiones del sujeto respecto de una norma, el estudio obvia una serie de factores relacionados con el individuo en sí (v.gr. impulsividad, autocontrol, emociones, personalidad, etc.), centrando el análisis únicamente en los factores que interaccionan entre el sujeto y el mensaje normativo. En particular se ha tratado de evaluar la influencia en el incumplimiento de las principales variables en las que se basa la disuasión: la certeza y severidad percibidas. Y, como puede verse por los resultados, y frente a lo que en

\footnotetext{
${ }^{13}$ Pueden consultarse las investigaciones de este grupo en: http://grdec.uab.cat/
} 
otros estudios se había sostenido, con respecto a la conducta de confinamiento podríamos decir que la disuasión desempeña un papel relevante en el cumplimiento normativo. En atención a los resultados del modelo matemático, la certeza percibida entró a formar parte del modelo como factor predictivo, mostrando la importancia de la misma en la prevención de conductas. Así, el incremento de una unidad en esta variable implicaría una reducción del 44,4\% de la probabilidad de incumplir. En este modelo la severidad percibida no entró, en cambio, en la línea de lo establecido por la literatura acerca de la eficacia de los distintos elementos de la disuasión, como factor predictivo. No obstante, no podemos descartar que tal factor no sea importante para la motivación al cumplimiento. De hecho, en el Anexo II se detallan los distintos pasos de regresión logística, y, precisamente en el modelo correspondiente al paso 7 puede observarse que la severidad sí entraba como factor predictivo, aunque por las razones detalladas en la descripción del modelo matemático, las pruebas estadísticas realizadas aconsejaran adoptar el modelo correspondiente al paso 6. Asimismo, en los análisis correlacionales podemos observar que la severidad mostraba una relación estadísticamente significativa y negativa con el incumplimiento de modo que, a menor severidad percibida mayor era el incumplimiento. ¿Pero qué severidad: la de la sanción administrativa o la del castigo penal? Si atendemos al análisis de varianza, los resultados nos indican que la diferencia en el incumplimiento entre los que perciben que la sanción a imponer en caso de incumplimiento sería la económica y los que perciben que la sanción a imponer sería la pena de prisión no es estadísticamente significativa. Conforme a esto, y pese a que es obvio que el Derecho penal también permite la sanción con multas y en particular así es para esta conducta, lo cierto es que la severidad percibida relevante y que interacciona con el incumplimiento no es aquella que sólo es posible en el caso de infracción penal, que es la pena de prisión. Por decirlo de otro modo, la vía administrativa, que también incluye la multa, sería suficiente para la prevención de conductas infractoras y, por tanto, el mensaje normativo penal de la pena de prisión no sería necesario si lo que se persigue es la prevención de conductas que incumplen el estado de alarma.

Estos hallazgos contradicen los obtenidos en otros modelos de cumplimiento normativo en el contexto de la pandemia. Así, por ejemplo, en el modelo matemático del estudio de cumplimiento de las medidas de distanciamiento social realizado por RooIj et al. (2020) no entran como variables predictoras ni la severidad ni la certeza percibidas. Tampoco en los modelos de regresión logística del estudio de KooIstRa et al. (2020). Sin embargo, resulta difícil comparar ambos estudios con el presente debido a que estos resultados pueden deberse a las diferencias entre España y Estados Unidos y Reino Unido respecto de las obligaciones de confinamiento y distanciamiento social, habiendo sido éstas más estrictas en nuestro país que en los anglosajones.

Como se ha adelantado, los resultados en relación con el enfoque de la disuasión parecen oponerse, cuanto menos a primera vista, a los obtenidos en la literatura que ha evaluado su eficacia en ámbitos normativos como la seguridad vial (MIRÓ LLINARES y BAUTISTA ORTUÑO, 2013) o la vulneración de los derechos de propiedad intelectual en Internet (GóMEZ-BELLVís, 2019). En el primero, donde se evaluaban conductas como el exceso de velocidad, la severidad producía un efecto incluso contrario a la hipótesis de partida, es decir, a mayor severidad percibida mayor era el incumplimiento, algo que los autores atribuían a la erosión de la legitimidad de la norma de conducta para imponer sanciones penales. Sin embargo, la explicación de MiRó LLINARES y BAUTISTA ORTUÑO (2013) de este efecto inverso de la severidad como consecuencia de una posible erosión de la legitimidad, no tiene por qué resultar contradictoria con los 
resultados del presente trabajo, especialmente si tenemos en cuenta que la norma de conducta evaluada tiene como característica que es percibida como legítima. Para los participantes de este estudio incumplir está moralmente mal, y el incumplimiento es percibido como grave, por lo que la interacción entre el modelo de la disuasión y de la legitimidad va, en este caso, en la misma dirección. Por otro lado, y respecto a la aparente contradicción de los resultados de este estudio con la afirmación de Gómez-Bellvís (2019) para la infracción de los derechos de autor en Internet de que ni la severidad ni la certeza percibidas resultaban relevantes para el cumplimiento normativo, es importante, a mi parecer, tener en consideración que los ámbitos normativos analizados y el contexto en el que son evaluados son radicalmente distintos. En particular en el estudio referenciado se trataba de un ámbito normativo en el que la certeza percibida es tan baja que resulta muy difícil que pueda desplegar alguna eficacia. En cambio, el contexto en el que se ha evaluado el cumplimiento de la norma de confinamiento tiene como especial característica precisamente una alta certeza de la sanción. Es decir, que de lo que nos informa esta aparente discrepancia de resultados es de algo que la literatura ya había intuido previamente (ORTIZ DE URBINA), que la configuración del mensaje normativo en términos disuasorios, poniendo especial acento en el castigo, puede ser eficaz a partir de unos determinados niveles de certeza aceptables, tales que resulten suficientes para que motive a las personas a cumplir con la norma porque sepan con cierta seguridad que si la incumplen el castigo tiene muchas probabilidades de materializarse. Pero, a la vez, y en este mismo contexto, la severidad seguiría desempeñando un papel residual: en el caso que nos ocupa, manteniendo estos niveles de certeza alta, la severidad procedente de la infracción administrativa sería suficiente para motivar al cumplimiento, no necesitando un aumento de la misma en términos cualitativos con la injerencia del Derecho penal. A mi parecer resulta francamente difícil mantener tales niveles de certeza a medida que el contexto va cambiando y se va flexibilizando. Solo un Estado que pudiera permitirse en términos democráticos y económicos vigilar sin cuartel y sine die a sus ciudadanos para inculcarles la certeza de que si incumplen o desobedecen a la norma serán castigados con la severidad suficiente podrá motivar al cumplimiento de las normas por medio de un modelo coercitivo. Pero, a mi juicio, este Estado estaría lejos de uno que pudiera lograr un cumplimiento voluntario porque la norma merezca ser obedecida en términos de legitimidad sustantiva y procedimental, y porque represente el modelo social de conducta a seguir. En este sentido, tanto por cuestiones pragmáticas - ya que a medida que vamos avanzando en la desescalada va a ser cada vez más complejo asegurar la certeza percibida de la sanción- como por cuestiones deontológicas teniendo en cuenta que es más deseable un modelo de intervención consensual que logre el cumplimiento voluntario de la norma-, es conveniente analizar y comprender la importancia de otros factores explicativos procedentes de enfoques basados en la legitimidad y la influencia social en el cumplimiento de las normas.

Respecto de las variables de la influencia social se ha encontrado una correlación significativa entre la norma descriptiva y prescriptiva y el incumplimiento en la dirección de que la baja percepción de la desaprobación negativa del grupo de referencia se relaciona con el incumplimiento, así como que la creencia de que la gente realiza la conducta infractora se relaciona con el incumplimiento. Resultados convergentes obtuvieron KooI et al. (2020); BoGG y MilAD (2020), KUIPER et al. (2020). NivetTe et al. (2020) también encontraron una relación entre el incumplimiento y tener amigos que realizan conductas antisociales. En todo caso, de las dos variables de influencia social, solo la norma descriptiva ha entrado a formar parte del modelo de regresión logística. En este sentido, por cada incremento en una unidad de la variable "norma descriptiva", es decir, por cada incremento en una unidad en la percepción que 
mucha gente incumple, aumenta las probabilidades de incumplir en un 62,9\%. En atención a estos resultados creo con KUIPER et al. (2020) que una estrategia fundamental para prevenir el incumplimiento teniendo en cuenta la importancia de la influencia social, ha sido la comunicación por las autoridades a través de los medios de comunicación que la mayoría de la población estaba cumpliendo con la norma que prescribía el confinamiento.

Si bien se ha encontrado que la influencia social, especialmente la norma descriptiva, es relevante para prevenir el incumplimiento, también es importante señalar que tal y como se ha descrito más arriba, el cumplimiento de las normas también puede depender del sistema de valores del individuo (MIRÓ LLINARES, 2017). De hecho, las correlaciones más fuertes se han dado entre las variables de la legitimidad sustantiva y el incumplimiento, de tal modo que cuanto peor se juzgue moralmente la conducta infractora mayor será el cumplimiento y cuanto más grave le parezca al sujeto la infracción también más cumplirá. Además, la gravedad percibida de la conducta ha entrado a formar parte del modelo de regresión logística. En este sentido, JACKSON, POSCH, BRADFORD, HOBSON y KYPRIANIDES (2020) no encontraron una relación predictiva entre las variables de la disuasión y de la legitimidad procedimental (policial y legal), pero encontraron una relación entre la alineación moral con la norma y su cumplimiento. En concreto, cuando les preguntaron a los participantes si pensaban que era correcto tipificar el distanciamiento social, el $90 \%$ de los participantes consideró que era correcto o completamente correcto. Asimismo, KUIPER et al. (2020) encontraron una relación estadísticamente significativa con el alineamiento moral a la norma y el cumplimiento de la misma en el sentido de que la gente que cree en términos morales que debe seguirse la norma, cumple más.

En este sentido, dada la importancia de las variables relacionadas con la legitimidad sustantiva, pero también de la influencia social sería recomendable indagar en la configuración de mensajes normativos que tengan en cuenta la importancia de los juicios morales de la ciudadanía y cómo estos, como seres sociales, también se ven influenciados por la conducta de los demás, y, aprovechar de este modo el potencial expresivo de las normas y el poder persuasivo de los mensajes morales (JACKSON et al. 2020; LunN, TIMMONS, BELTON, BARJAKOVÁ, Julienne y Lavin, 2020; Everett, Colombatto, Chituc, Brady y Crockett, 2020).

Por otro lado, la labor de los agentes de seguridad durante los días de confinamiento ha sido esencial para aumentar la certeza de la sanción, pero también dado el contacto con los ciudadanos resulta necesario evaluar la interacción entre la legitimidad procedimental y el cumplimiento. De conformidad con los análisis, se ha encontrado una relación negativa y estadísticamente significativa entre la actitud de obediencia a la ley y el incumplimiento, de tal manera que a menor actitud de obediencia presente en el sujeto mayor es el incumplimiento. Además, esta es una de las variables que han entrado a formar parte del modelo de regresión lineal mostrando que por cada incremento en una unidad de esta variable se reduce en un $44,4 \%$ la probabilidad de incumplir. En este sentido, durante el contexto de la pandemia resultan relevantes los lazos de la comunidad con las normas y sus autoridades para que se puedan desplegar actitudes positivas como las de obediencia a la ley, que, además podríamos poner en relación con los resultados acerca del apoyo a la propia medida de confinamiento, donde la mayoría no solo la apoyaba ampliamente, sino que apoyaría una prórroga del mismo. En este sentido, también encuentran esta relación NIVETTE et al. (2020) quienes entienden que a la luz de sus resultados que para aumentar el cumplimiento voluntario de las medidas contra el SARS-COV-2 es necesario realizar campañas de salud pública que aumenten la obligación moral y la confianza en las autoridades. 
En relación con otras variables relacionadas con la interacción de la muestra y los agentes de la autoridad, si bien la calificación de éstos en términos de honestidad, imparcialidad, etc., encontró una correlación negativa y estadísticamente significativa con el incumplimiento, no entró a formar parte del modelo de regresión logística. Pero sí es una variable predictora el haber sido parado por la policía durante el confinamiento. Ahora bien, es posible que su introducción en el modelo se deba más a que precisamente la gente que ha salido a la calle y, por lo tanto, ha incumplido haya sido parada más por la policía.

Por último, y respecto de las variables contextuales, pese a que muchos medios de comunicación y manifestaciones públicas por parte de políticos que han sugerido que variables como el tamaño de la vivienda afecta al confinamiento, no lo hace en términos de cumplimiento. Sin embargo, sí se ha encontrado una relación entre el incumplimiento y variables como la cohabitación con varias personas en el mismo domicilio, tener hijos menores a cargo durante el confinamiento, las horas de uso de Internet al día, y, teletrabajar. Sin embargo, las relaciones mostradas eran tan modestas que no hemos podido más que aceptar las hipótesis de forma parcial. Asimismo, ninguna de ellas ha entrado a formar parte del modelo de regresión logística.

Finalmente, no se han encontrado relaciones significativas entre las variables sociodemográficas "nivel de estudios" al igual que en otros estudios (PLOHL y MusiL, 2020); ni tampoco respecto de la ideología, en la línea de los hallazgos de RooIj et al. (2020), KooISTRA et al. (2020) y, KUIPER et al. (2020), y en contra de los hallazgos de KuSHNER, GADARINA, GOODMAN y PEPINSKY (2020). No obstante, el sexo sí resultó ser una variable que correlacionaba con el incumplimiento, pero estos resultados no pueden ser interpretados sin la debida cautela ya que la muestra presenta un sesgo de género considerable.

Antes de finalizar, resulta necesario apuntar a ciertas limitaciones del presente estudio que pueden afectar a las interpretaciones de los resultados. En primer lugar, aunque la muestra está integrada por un tamaño considerable de participantes $(\mathrm{N}=1312)$, se trata de una muestra que no es representativa de la población española, por lo que los resultados no se pueden generalizar. Además, la muestra tiene sesgos en cuanto al género ya que hay muchas más mujeres en la muestra que hombres, y, también respecto del nivel máximo de estudios. Por otro lado, y, a pesar de que las variables se han operativizado siguiendo diferentes estudios en la materia, posiblemente el contexto actual puede haber generado efectos de deseabilidad social (Daoust, Nadeau, Dassonneville, Lachapelle, BélangerSAVoie y Linden, 2020). No obstante lo anterior, los resultados del presente estudio pretenden sumarse a los hallazgos sobre el cumplimiento normativo en general, pero en particular en el contexto de la pandemia. En este sentido, tal y como se ha analizado en detalle, si bien es cierto que el enfoque de la disuasión en el contexto del confinamiento más estricto puede desplegar su eficacia, especialmente porque aumenta de manera considerable la certeza percibida del castigo, no es menos cierto que el hecho de que las condiciones de certeza pueden disminuir a medida que avancemos en la desescalada, así como los elevados recursos que supone mantener tales niveles de certeza, quizás deban plantearse otras estrategias preventivas que, con menos recursos, puedan obtener igualmente un mayor cumplimiento de la norma y, al mismo tiempo, reducir la expresión punitiva y el modelo coercitivo en que se basa la prevención general negativa. En todo caso, es necesario investigar el fenómeno del cumplimiento normativo en esta materia superando los límites metodológicos señalados y abriendo nuevas líneas de investigación. Así, en el modelo de regresión de todas las variables planteadas en el estudio solo entraron a formar parte como variables predictoras la gravedad percibida, la certeza percibida de la sanción, la norma 
descriptiva, la actitud de obediencia a la ley y el haber sido parado por la policía. Solo estas cinco variables pueden explicar el $42 \%$ de la varianza $\left(R^{2}=0,241\right.$ [Cox y Snell], 0,421 [Nagelkerke]), porcentaje que no resulta nada desdeñable, pero que sugiere la existencia de otras variables no incluidas en el estudio que también pueden estar detrás del incumplimiento.

\section{Bibliografía}

Alberto Alonso Rimo, (2020), “Aspectos esenciales del delito y la infracción administrativa de desobediencia a la autoridad (más allá de la pandemia de COVID-19)”, Diario La Ley, no 9689.

Francisco Javier Álvarez García (2013), "Las desobediencias en Derecho Penal”, Eunomía. Revista en Cultura de la Legalidad, 4.

Francisco Javier Álvarez GaRCía y Mar CARRASCo ANDRINo (2018), "Orden público, principio de autoridad y función pública”, En Suárez López, J. M., Barquín Sanz, J., Benítez Ortúzar, I. F., Jiménez Díaz, M. J., Sáinz Cantero Caparrós, J. E. (Coords.). Estudios jurídicos penales y criminológicos en homenaje a Lorenzo Morillas Cueva. Madrid: Dykinson.

Francisco Alvira-Martín (1984), "El efecto disuador de la pena", Estudios Penales y Criminológicos, vol. II. Cursos e Congresos ${ }^{\circ}{ }^{\circ} 2$. Sevizo de Publicacions de Universidade de Santiago de Compostela.

Carlos Alberto AmOEDo-Souto (2020), "La genealogía autoritaria del régimen sancionador del estado de alarma. Del "Fast and Furious" al "Jurassic Park"”. Disponible en: http://www.aepda.es/AEPDAEntrada-2775-La-genealogia-autoritaria-del-regimensancionador-del-estado.aspx

Robert APEL (2013), “Sanctions, perceptions, and crime: Implications for criminal deterrence”, Journal of quantitative Criminology, 29.

Manuel ATIENZA (1989), “Contribución para una teoría de la legislación”, DOXA, 6.

Rebeca BAUTISTA ORTUÑO (2017), “¿Eres un ciberhater? Predictores de la comunicación violenta y el discurso de odio en Internet”, International e-Journal of Criminal Science, 11.

Gary S. BeCKeR (1968), “Crime and Punishment, An Economic Approach”, Journal of Political Economy, 76.

Jeremy Bentham (1789/2017), An introduction to the Principles of Morals and Legislation, Recuperado de: http://www.earlymoderntexts.com/assets/pdfs/bentham1780.pdf

Tim BoGG y Elizabeth MILAD (2020), "Slowing the Spread of COVID-19: Demographic, Personality, and Social Cognition Predictors of Guideline Adherence in a Representative US Sample”, Preprint DOI 10.31234/osf.io/yc2ga

Adam M Bossler (2019), "Perceived formal and informal sanctions on the willingness to commit cyber attacks against domestic and foreign targets”, Journal of Crime and Justice, 42(5), 599-615. 
Sylvain Brouard, Pavlos VASILOPoulos, y Michael BeCHer(2020), "Sociodemographic and psychological correlates of compliance with the Covid-19 public health measures in France", Canadian Journal of Political Science. Disponible en: https://www.cambridge.org/core/journals/canadian-journal-of-political-science-revuecanadienne-de-science-politique/article/sociodemographic-and-psychological-correlates-ofcompliance-with-the-covid19-public-health-measures-infrance/3704E20ABAF59BCD6842BAA307540BFE

Don BROwN (1978), “Arrest rates and crime rates: when does a tipping effect occur?”, Social Forces, 57.

Sergi CARDEnal Montraveta (2015), “Eficacia preventiva general intimidatoria de la pena?. Consecuencias para la decisión sobre la suspensión de su ejecución”, Revista Electrónica de Ciencia Penal y Criminología, 17-18.

Adolfo CARRETERo SÁNCHEZ (2015), "El delito de atentado, resistencia y desobediencia a la autoridad y sus agentes tras la reforma del Código Penal”, La Ley, (7745).

Francisco Javier CASTRO-TOLEDo (2019), “Obediencia a la ley y apoyo al sistema de justicia penal en colectivos vulnerables: semejanzas y diferencias con la población general”, Revista General de Derecho Penal, (32).

Mitchel B. CHAmLin (1991), "A longitudinal analysis of the arrest-crime relationship: A further examination of the tipping effect", Justice Quarterly, 8.

Robert B. CiaLdini y Noah J. GoldSTEIN (2004), “Social influence: compliance and conformity”, Annual Review of Psychology, 55.

Robert B. Cialdini, Linda J. Demaine, Brad J. Sagarin, Daniel W. BarRetT, Kelton RhoAds, y Patricia L. WINTER (2006), "Managing social norms for persuasive impact”, Social Influence, 1(1).

Robert B. Cialdini, Carl A. Kalgren, y Raymond R. Reno (1991), “A Focus Theory of Normative Conduct: A theoretical refinement and reevaluation of the role of norms in human behaviour", Advances in Experimental Social Psychology, vol. 24, págs. 201-234. Disponible en Internet en: http://www.influenceatwork.com/wp-content/uploads/2015/05/AFocus-Theory-of-NormativeConduct.pdf

David Colomer Bea (2020), "Delito de desobediencia e incumplimiento de la prohibición de circular sin causa justificada durante el estado de alarma”, Diario La Ley, (9629)

María Luisa Cuerda ARNAu (2015), “Atentados y resistencia (arts. 550 y ss.)”, En Gonzalez Cussac, J. L. (Dir.), Comentarios a la Reforma del Código Penal de 2015 (2 ${ }^{\mathrm{a}}$ ed.). Valencia: Tirant lo Blanch.

Jean- François DaOust, Richard NADEAU, Ruth DASSONNEVIlLe, Erick LACHAPELLE, Éric BÉLANGER, Justin SAvoIE, y Clifton VAN DER LINDEN (2020), "How to survey citizens' compliance with COVID-19 public health measures? Evidence from three survey experiments", Journal of Experimental Political Science, 1-8, Disponible en: https://osf.io/preprints/socarxiv/gursd/ 
Francisco Salvador De la Fuente CARDona (2018), "Proporcionalidad penal: a propósito de la desobediencia leve y de la falta de respeto y consideración debida a la autoridad”, Revista Jurídica de la Universidad Autónoma de Madrid, (37).

Norberto Javier De la MATA BARRANCo, (2020). “¿Delito de desobediencia por incumplimiento reiterado de una norma administrativa?”, Almacén de Derecho, 9 de abril de 2020. Disponible en: https://almacendederecho.org/delito-de-desobediencia-por-incumplimiento-reiterado-deuna-norma-administrativa/

Whitney DeCAMP (2009), "Internet Scallywags: A Comparative Analysis of Multiple Forms and Measurements of Digital Piracy”, Western Criminology Review.

José Luís DíEz RIPOLLÉs (2013), La racionalidad de las leyes penales: práctica y teoría. Madrid: Trotta.

Jacobo DOPICo GóMEZ-ALLER (2020), “¿Puede calificarse como delito de desobediencia grave a la autoridad (art. 556.1 del Código Penal) el mero incumplimiento de la prohibición de circular por las vías públicas durante el período de confinamiento?”, en Brito Siso, C., \& Maroto Calatayud, M. (Eds.). Guías sectoriales Covid-19. Sección de Derechos Humanos. Ilustre Colegio de Abogados de Madrid. Disponible en: https://web.icam.es/bucket/Guia\%20DDHH.pdf

Libor DuSEK y Christian TRAXLER (2020), “Learning from Law Enforcement”, CESifo Working Paper, 8043.

Jim A. C.Everett, Clara Colombatto, Vladimir Chituc, William J. Brady, y Molly J. Crockett (2020), "The effectiveness of moral messages on public health behavioral intentions during the COVID-19 pandemic", Disponible en: https://psyarxiv.com/9yqs8

Jeffrey FagAn y Tom R. TYLER (2005), “Legal socialization of children and adolescents”, Soc. Justice Res, 18(3), 217-42

Joel Feinberg (2011), “The Expressive Function of Punishment”. En Tonry, M. (Ed.). Why punish? How Much?, Oxford University Press.

Paul Johann Anselm Feuerbach (2007)Tratado de Derecho penal. (Traducción de Eugenio Zaffaroni e Irma Hagemeier). Hamurabi, Buenos Aires.

Juan Antonio García Amado (2019), "Derecho Penal y análisis económico del Derecho. ¿Vale la pena lo que cuesta?”, en Castañeda Méndez/Pérez Ramos/Bocanegra Landeras (Coords.), El costo de la justicia. Corrupción, Género, Terrorismo y Medio Ambiente. Ponencias del I Congreso Internacional en Filosofía en Derecho \& Análisis Económico, MRCI, Perú, La Libertad, Trujillo, 2019.

Nicolás GaRCía Rivas (2015), "Delitos de atentado, resistencia y desobediencia”, en Quintero Olivares, G. (Dir.), Comentario a la reforma penal de 2015. Thomson Reuters Aranzadi.

Sandrine GAYMARD (2009), "Norms in social representations: two studies with French young drivers”, The European Journal of Psychology Applied to Legal Context, 1 (2). 
Noah J. GoldDSTEIn, Robert B. Cialdini y Vladas GRisKeVICIUS (2008), “A room with a viewpoint: using social norms to motivate environmental conservation in hotels", Journal of Consumer Research, 35 .

Ana B. Gómez Bellvís (2019), “Crónica de una ineficacia anunciada: Un estudio sobre los factores asociados al cumplimiento en el ámbito de la propiedad intelectual”, Indret, (1).

Ana B. Gómez Bellvís y Fernando Miró LlinARes (2019), "Do or do not, there is no "try": an exploratory quasi-experimental study of intuitions of justice applied to attempt and completion of the crime of homicide”, Revista Española de Investigación criminológica, (17).

Ana B. Gómez Bellvís y Fernando Miró LlinARes (2020), “¿Por qué descargamos contenidos sin autorización en Internet? Un estudio exploratorio de los factores asociados al incumplimiento en el ámbito de la propiedad intelectual en el ciberespacio", en Fuentes Soriano, O. (Dir.). Era Digital, Sociedad y Derecho. Valencia: Tirant lo Blanch.

Amanda Graham, Francis T. Cullen, Justin T. Pickett, Cheryl Lero jonson, Murat Haner y Melissa M. SloAn (2020), "Faith in Trump, Moral Foundations and Social Distancing Defiance During the Coronavirus Pandemic", Foundations and Social Distancing Defiance During Coronavirus Pnademic (April 22, 2020). Disponible en: https://osf.io/preprints/socarxiv/fudzq

Emma GRAHAM-HARRISONY y Lily KuO (2020), “China's coronavirus lockdown strategy: Brutal but effective”, The Guardian, 2020, vol. 20.

Michael Greenstone, y Vishan Nigam (2020), “Does Social Distancing Matter?”, University of Chicago, Becker Firedman Institute for Economics Working Paper, no. 2020-26, Preprint: https://papers.ssrn.com/sol3/papers.cfm?abstract id $=3561244$

Craig A. HARPER, Liam P. SATChell, Dean Fido, y Robert D. LATZMAn (2020). "Functional Fear Predicts Public Health Compliance in the COVID-19 Pandemic", International Journal of Mental Health and Addiction. Disponible en: https://link.springer.com/content/pdf/10.1007/s11469020-00281-5.pdf

Tatjana HöRnle (2015). Teorías de la pena. (Traducción de Nuria Pastor Muñoz). Centro de Investigación en Filosofía y Derecho, Universidad Externado de Colombia.

Jonathan JACKSON, Crhis Posch, Ben BRANDFORD, Zoe HobSON y Arabella KyPRIANIDES (2020), "The lockdown and social norms: why the UK is complying by consent rather than compulsion”, British Policy and Politics, Blog Entry (27 Apr. 2020).

Carmen JuANATEy Dorado (1997). El delito de desobediencia a la autoridad: (artículo 556 del Código Penal. Valencia: Tirant lo Blanch.

Carmen JuAnatey Dorado (2016), "Orden público, paz pública y delitos de resistencia, desobediencia y desórdenes públicos tras la reformas de 2015”, Cuadernos de Política Criminal, 120.

Dan M. KAHAN (1997), “Social influence, Social Meaning, and Deterrence”, Virginia Law Review, 83(2). 
Dan M. KaHAN y Martha C. Nussbaum (1996), “Two conceptions of emotion in Criminal Law”, Columbia Law Reivew, vol. 96, núm. 2.

Kimberly KessLer y Stephen J. Morse (2016). Legal, Moral, and Metaphysical Truths: The Philosophy of Michael S. Moore, Oxford University Press.

Emmeke B. Kooistra, Chris Reinders Folmer, MalouKe EsRa Kuiper, Elke Olthuis, Megan BrownleE, Adam FInE, y Benjamin VAN RooIJ, B. (2020), "Mitigating COVID-19 in a Nationally Representative UK Sample: Personal Abilities and Obligation to Obey the Law Shape Compliance with Mitigation Measures", (May 11, 2020). Available at SSRN: https://ssrn.com/abstract $=3598221$

Malouke EsRa Kuiper, Anne Leonore De Bruijn, Chris Reinders Folmer, Elke Olthuis, Megan Brownlee, Emmeke Barbara Kooistra, Adam Fine, Benjamin Van Rooij (2020), “The intelligent lockdown: Compliance with COVID-19 mitigation measures in the Netherlands”, Preprint.

Shana Kushner Gadarian, Sara Wallace Goodman y Thomas B. PePinsky (2020), "Partisanship, health behavior, and policy attitudes in the early states of the COVID-19 pandemic", Disponible en: https://papers.ssrn.com/sol3/papers.cfm?abstract_id=3562796

José María LóPEz RiBA (2020), "La gestión policial de la crisis sanitaria. En Contexto y Acción. 1 de abril de 2020”, Disponible en: https://ctxt.es/es/20200401/Politica/31731//ose-Maria-LopezRiba-policia-coronavirus-confinamiento-estado-alarma.htm

Peter. D. Lunn, Shane Timmons, Cameron A. Belton, Martina Barjaková, Hanna Julienne, y Ciarán LAVIN, C. (2020), "Motivating Social Distancing During the COVID-19 Pandemic: An Online Experiment”, Disponible en: https://www.esri.ie/pubs/WP658.pdf

Vicente MAGRO SERVET (2020), "El reproche penal a los actos de desobediencia a agentes de la autoridad en el período de Estado de Alarma por el Coronavirus”, Diario La Ley, (9604).

MARQUÉS DE BECCARIA (1764/2011), De los delitos y las penas, Fondo de Cultura Económica.

Juanjo Medina (2003), “Inseguridad ciudadana, miedo al delito y policía en España”, Revista Electrónica de Ciencia y Criminología, 05-03.

Fernando Miró LuINARES (2017), “La función de la pena ante "el paso empírico” del Derecho penal”, Revista General de Derecho Penal, 27.

Fernando MiRÓ LLINARES (2018), "Hechos en tierra de normas: Una introducción epistemológica a la relevancia de la realidad fáctica en el Derecho penal”, en Suárez López, J. M., Barquín Sanz, J., Benítez Ortúzar, I. F., Jiménez Díaz, M. J., Sáinz Cantero Caparrós, J. E. (Coords.). Estudios jurídicos penales y criminológicos en homenaje a Lorenzo Morillas Cueva. Madrid: Dykinson.

Fernando Miró Llinares, (2020), “Cientismo, dogmatismo y Derecho penal”, en Olaizola Nogales, I., Trapero Barreales, M. A., Roso Cañadillas, R., Lombana Villalba, J. A., de Vicente Remesal, J., Paredes Catañón, M. (Dirs.)., Libro Homenaje al Profesor Diego-Manuel Luzón Peña con motivo de su $70^{\circ}$ aniversario, Reus, Barcelona. 
Fernando Miró LLINARES y Francisco Javier CASTRO-TOLEDO (en prensa). La legitimidad de (y en) RIMES. Justicia procedimental y legitimidad sustantiva y medición de la política criminal. Manuscrito cedido por los autores.

Fernando Miró LLINARES y Ana B. GóMEZ-BELlVís (2020), “Freedom of expression in social media and criminalization of hate speech in Spain: evolution, impact and empirical analysis of normative compliance and self-censorship", Spanish Journal of Legislative Studies, 1.

Fernando Miró LlinARES y Rebeca BAUTISTA ORTUÑo (2013), “¿Por qué cumplimos las normas penales?: Sobre la disuasión en materia de seguridad vial”, Indret, (4).

Michael S. Moore (1987), “The Moral Worth of Retribution”, en Schoeman, F. Responsibility, Character and Emotions: New essays in moral psychology. Cambridge University Press.

Daniel NAGiN (2013), “Deterrence in the Twenty-frist Century”, Crime and Justice, 42.

Daniel Nagin y Cody W. TeleP (2017), "Procedural justice and legal compliance”, Annual Review of Law and Social Science, 13.

Amy Nivette, Denis Ribeaud, Aja Murray, Annekatrin Steinhoff, Laura Bechtiger, Urs HePP, Lilly SHANAHAN, Manuel EISNTER, (2020), "Non-compliance with COVID-19-related public health measures among young adults: Insights from a longitudinal cohort study”, Social Science and Medicine , 1982. Disponible en: https://osf.io/preprints/socarxiv/8edbj/

Íñigo ORTIZ DE URBINA (2003), “Roxin y la dogmática político-criminalmente orientada”, en La influencia de la ciencia penal alemana en Iberoamérica: en homenaje a Claus Roxin. Instituto Nacional de Ciencias Penales.

José Manuel PAREDes CASTAÑón (2013), La justificación de las leyes penales. Valencia: Tirant lo Blanch

Raymond PATERnoster (2010), "How much do we really know about criminal deterrence", The Journal of Criminal Law and Criminology, 100.

Raymond Paternoster (2018), "Perceptual deterrence theory”, en Nagin, D. S, Cullen, F. T., \& Jonson, C. L. (Eds.). Deterrence, choice, and crime: Contemporary perspectives. New York: Routledge.

Michael PAWLIK (2004), Person, subject, Burger. Zur Legitimation von Strafe, Duncker und Humblot, Berlín.

Nejc PlOHL y Bojan MusIL (2020), "Modeling compliance with COVID-19 prevention guidelines: The critical role of trust in science", Psychology, Health \& Medicine. Disponible en: https://psyarxiv.com/6a2cx/

Travis C. PRATT, ET AL. (2006), “The empirical status of deterrence theory: A meta-analysis”, en Cullen F. T., Wright, J. P., Blevins, K. R. (Coords.). Taking stock: The status of criminological theory. Nueva Jersey: Transaction Publishers. 
Miguel Ángel PRESNo Linera (2020), “Estado de alarma y derechos fundamentales”, en Brito Siso, C., y Maroto Calatayud, M. (Eds.). Guías sectoriales Covid-19. Sección de Derechos Humanos. Ilustre Colegio de Abogados de Madrid. Disponible en: https://web.icam.es/bucket/Guia\%20DDHH.pdf

Pablo RANDo CASERMEIRO (2019), “Disuasión y piratería”, Indret, (3).

Santiago Rendondo IlLESCAS y Vicente GARRIDo Genovés, V. (2013). Principios de Criminología (4 ${ }^{\mathrm{a}}$ ed.). Valencia: Tirant lo Blanch.

Paul H. Robinson (2013). Intuitions of Justice and the Utility of Desert. New York: Oxford University Press.

Paul H. Robinson (2012), Principios distributivos del Derecho Penal. A quién debe sancionarse y en qué medida. (Traducción de Manuel Cancio Meiliá y Íñigo Ortiz de Urbina Gimeno), Marcial Pons, Madrid.

Paul H. Robinson, Geoffrey P. Goodwin, y Michael D. ReISIG(2010), “The disutility of injustice”, NYUL Rev. 85, 1940.

Daniel RodRíguez HorCAJo (2016). Comportamiento humano y pena estatal: disuasión, cooperación y equidad. Marcial Pons, Madrid.

Benjamin VAn RooIJ, Anne Leonore De Bruijn, Crhis Reinders Folmer, Emmeke Kooistra, Malouke Esra Kuiper, Megan Brownlee, Elke Olthuis, y Adam Fine (2020), “Compliance with COVID-19 Mitigation Measures in the United States”, Disponible en: https://papers.ssrn.com/sol3/papers.cfm?abstract_id=3582626

Rick TRINKNER y Tom. R. TYLER (2016), "Legal socialization: Coercion versus consent in an era of mistrust”, Annual Review of Law and Social Science, 12, 417-439.

Tom R. TyLer (2017), “Procedural justice and policing: A rush to judgment?”, Annual Review of Law and Social Science, 13.

Tom R. TYLeR (1997), “Compliance with Intellectual Property Laws: A Psychological Perspective”, New York University Journal of International Law and Policy, 29.

Tom R. TYLER (2003), "Procedural justice, legitimacy, and the effective rule of law”, Crime and justice, 30, 283-357.

Tom R. TYLER (2006), "Psychological perspectives on legitimacy and legitimation”, The Annual Review of Psychology, 57, 375-400.

Tom R. TYLER (2006). Why People Obey the Law. Princeton: Princeton University Press.

Tom R. TYLER (2010). Why People Cooperate. The Role of Social Motivations. Princeton University Press. 
Annelies WiLDER-SMith y David O. FREEDMAN (2020), "Isolation, quarantine, social distancing and community containment: pivotal role for old-style public health measures in the novel coronavirus (2019-nCoV) outbreak", Journal of Travel Medicien. doi: 10.1093/jtm 


\section{Anexo I}

Tabla 7. Resumen de las variables dependiente e independientes incluidas en el estudio

\begin{tabular}{|c|c|c|c|}
\hline & VARIABLE & ÍTEM & ESCALA \\
\hline & $\begin{array}{l}\text { Cumplimiento informado de la } \\
\text { medida de confinamiento }\end{array}$ & $\begin{array}{l}\text { Desde que se decretó el Estado de } \\
\text { alarma el } 14 \text { de marzo, ¿con qué } \\
\text { frecuencia ha salido usted a la calle } \\
\text { fuera de los casos permitidos o } \\
\text { abusando de los casos permitidos (por } \\
\text { ejemplo, ir a comprar más de una vez } \\
\text { al día o más de lo necesario, sacar a la } \\
\text { calle a mascotas más veces de lo } \\
\text { necesario, o cualquier otra situación } \\
\text { similar)? }\end{array}$ & $\begin{array}{l}\text { Ninguna vez } \\
\text { De } 1 \text { a } 3 \text { veces } \\
\text { De } 4 \text { a } 6 \text { veces } \\
\text { De } 7 \text { a } 9 \text { veces } \\
\text { De } 10 \text { a } 12 \text { veces } \\
\text { De } 13 \text { a } 15 \text { veces } \\
\text { Más de } 15 \text { veces }\end{array}$ \\
\hline \multirow[t]{4}{*}{ Disuasión } & Miedo al contagio & $\begin{array}{l}\text { A día de hoy, ¿en qué medida tiene } \\
\text { miedo de ser contagiado? }\end{array}$ & $\begin{array}{l}0=\text { No tengo ningún miedo y } 10=\text { Tengo } \\
\text { mucho miedo }\end{array}$ \\
\hline & Miedo a contagiar & $\begin{array}{l}\text { A día de hoy, ¿en qué medida le } \\
\text { preocupa que usted pueda contagiar a } \\
\text { otra persona? }\end{array}$ & $\begin{array}{l}0=\text { No me preocupa en absoluto } \\
10=\text { Me preocupa absolutamente }\end{array}$ \\
\hline & Severidad percibida & $\begin{array}{l}\text { ¿Cuál cree que es la sanción máxima } \\
\text { que podría usted recibir por incumplir } \\
\text { sin causa que lo justifique su } \\
\text { obligación de permanecer en el } \\
\text { domicilio? }\end{array}$ & $\begin{array}{l}\text { Ninguna sanción } \\
\text { Multa inferior a } 100 \text { euros } \\
\text { Multa de } 100 \text { a } 300 \text { euros } \\
\text { Multa de } 301 \text { a } 600 \text { euros } \\
\text { Multa de } 601 \text { a } 1000 \text { euros } \\
\text { Multa de más de } 1000 \text { euros } \\
\text { Prisión de } 3 \text { meses a } 1 \text { año } \\
\text { Prisión de más de } 1 \text { año a } 5 \text { años } \\
\text { Prisión de más de } 5 \text { años a } 10 \text { años } \\
\text { Prisión de más de } 10 \text { años }\end{array}$ \\
\hline & Certeza percibida & $\begin{array}{l}\text { ¿Qué probabilidad cree que habría de } \\
\text { que le sancionaran a usted si incumple } \\
\text { sin causa justificada la obligación de } \\
\text { permanecer en su domicilio? }\end{array}$ & $\begin{array}{l}0=\text { Nada probable } \\
10=\text { Totalmente probable }\end{array}$ \\
\hline \multirow[t]{2}{*}{ Influencia social } & Norma prescriptiva & $\begin{array}{l}\text { Piense ahora en las personas de su } \\
\text { entorno (familia, vecinos, etc.), ¿en } \\
\text { qué medida cree que desaprobarían o } \\
\text { se sentirían decepcionados con usted si } \\
\text { supieran que ha incumplido sin causa } \\
\text { justificada su obligación de } \\
\text { permanecer en casa? }\end{array}$ & $\begin{array}{l}0=\text { No lo desaprobarían en absoluto } \\
10=\text { Lo desaprobarían totalmente }\end{array}$ \\
\hline & Norma descriptiva & $\begin{array}{l}\text { En su opinión, ¿cuánta gente cree que } \\
\text { incumple } \sin \text { causa justificada la } \\
\text { obligación de permanecer en casa? }\end{array}$ & $\begin{array}{l}0=\text { Nadie lo hace } \\
10=\text { Todo el mundo lo hace }\end{array}$ \\
\hline \multirow[t]{2}{*}{ Legitimidad sustantiva } & Juicio moral sobre la conducta & $\begin{array}{l}\text { Ahora, pensando en términos morales, } \\
\text { es decir, en lo que está bien y lo que } \\
\text { está mal, díganos, ¿qué opinión le } \\
\text { merece el hecho de salir a la calle } \\
\text { injustificadamente durante el Estado } \\
\text { de alarma? }\end{array}$ & $\begin{array}{l}0=\text { No está mal en absoluto } \\
10=\text { Está totalmente mal }\end{array}$ \\
\hline & Gravedad percibida de la conducta & $\begin{array}{l}\text { ¿Cómo de grave le parecería que una } \\
\text { persona incumpla sin causa justificada } \\
\text { su obligación de permanecer en casa? }\end{array}$ & $\begin{array}{l}0=\text { No me parece grave en absoluto } \\
10=\text { Me parece absolutamente grave }\end{array}$ \\
\hline \multirow[t]{5}{*}{ Legitimidad procedimental } & $\begin{array}{l}\text { Apoyo a la norma adoptada por la } \\
\text { autoridad }\end{array}$ & $\begin{array}{l}\text { De forma general, ¿en qué medida } \\
\text { apoya usted la decisión de obligar a la } \\
\text { mayoría de los ciudadanos, salvo } \\
\text { excepciones, a permanecer en sus } \\
\text { casas durante el Estado de alarma? }\end{array}$ & $\begin{array}{l}0=\text { Me parece totalmente inadecuado } \\
10=\text { Me parece totalmente adecuado }\end{array}$ \\
\hline & $\begin{array}{l}\text { Apoyo futuro a la continuidad de la } \\
\text { norma }\end{array}$ & $\begin{array}{l}\text { Como sabe, el Gobierno decretó } 15 \text { días } \\
\text { más de Estado de alarma, ¿en qué } \\
\text { medida apoyaría usted que el Gobierno } \\
\text { volviese a decretar, por tercera vez, } \\
\text { otros } 15 \text { días de Estado de alarma y, } \\
\text { por tanto, llegar a los } 45 \text { días de } \\
\text { confinamiento? }\end{array}$ & $\begin{array}{l}0=\quad \text { Me parecería totalmente } \\
\text { inadecuado } \\
\text { 10= Me parecería totalmente adecuado }\end{array}$ \\
\hline & Haber sido parado por la policía & $\begin{array}{l}\text { Durante el periodo que llevamos en } \\
\text { Estado de alarma, ¿cuántas veces le } \\
\text { han parado los agentes de policía } \\
\text { cuando ha salido a la calle, con o sin } \\
\text { causa justificada para ello? }\end{array}$ & $\begin{array}{l}\text { No me han parado ninguna vez } \\
\text { Me han parado } 1 \text { vez } \\
\text { Me han parado } 2 \text { veces } \\
\text { Me han parado } 3 \text { veces } \\
\text { Me han parado más de } 3 \text { veces }\end{array}$ \\
\hline & Haber sido multado & $\begin{array}{l}\text { Durante estos días de Estado de } \\
\text { alarma, ¿le han multado por incumplir } \\
\text { con su obligación de permanecer en } \\
\text { casa? }\end{array}$ & $\begin{array}{l}\text { Sí } \\
\text { No }\end{array}$ \\
\hline & Actitud de obediencia a la ley & $\begin{array}{l}\text { A continuación, le vamos a presentar } \\
\text { una serie de afirmaciones. Por favor, } \\
\text { díganos en qué medida está de acuerdo } \\
\text { con ellas }\end{array}$ & $\begin{array}{l}0=\text { Totalmente en desacuerdo y } 10= \\
\text { Totalmente de acuerdo }\end{array}$ \\
\hline
\end{tabular}


Factores ambientales o Personas cohabitantes contextuales relacionados con el confinamiento
Calificación agentes de la autoridad

Metros cuadrados de la vivienda

Espacio al aire libre

Hijos

Teletrabajo

Horas de uso de Internet al día obligaciones durante el Estado de alarma, incluso si va en contra de lo que creen que es correcto

2. Siempre trato de seguir las obligaciones del Estado de alarma, incluso si creo que no son correctas 3. Desobedecer el Estado de alarma nunca está justificado

4. Si una persona sale a la calle y un policía le dice que se identifique o que se detenga, debe detenerse $e$ identificarse, aunque crea que lo que está haciendo es totalmente legal

P.26. A continuación, se le van a presentar una serie de afirmacione acerca de los agentes de la autoridad. Por favor, indíquenos en qué medido está de acuerdo con ellas

1. Profesionales y competentes

2. Son respetuosos con el trato a los ciudadanos

3. Son honestos

4. Son eficaces en la persecución de las infracciones estos días

5. Son imparciales en sus actuaciones

6. Son respetuosos con los derechos de los ciudadanos durante estos días

P. 34. Número de personas que conviven en el domicilio en el que se encuentra confinado, incluyéndose usted

P. 35. ¿Cuántos metros cuadrados tiene aproximadamente el domicilio en el que se encuentra confiando?

P. 36. ¿Dispone de balcón, terraza, jardín o cualquier espacio al aire libre? En caso de tener varios, seleccione el más grande

p. 37 ¿Tiene hijos o menores a su cargo?

P. 42. ¿Se encuentra teletrabajando actualmente?

P. 43. Desde que se decretó el Estado de alarma, ¿Cuánto tiempo diría usted que pasa aproximadamente haciendo uso de Internet?
$0=$ Totalmente en desacuerdo y $10=$ Totalmente de acuerdo

1,2,3,4,5,6,7,8,9,10, más de 10

Menos de 25 metros cuadrados Entre 25 y 50 metros cuadrados

Entre 51 y 75 metros cuadrados Entre 76 y 100 metros cuadrados Entre 101 y 120 metros cuadrados Más de 120 cuadrados No

Balcón

Terraza

Jardón

Otro

Sí/NO

Sí

No

0 horas al día

Entre 1 y 2 horas al día

Entre 3 y 4 horas al día

Entre 5 y 6 horas al día

Entre 7 y 8 horas al dí

Entre 9 y 10 horas al día

Entre 11 y 12 horas al día

Más de 12 horas al día 


\section{Anexo II}

Tabla 8. Resultado de las regresiones logísticas binarias del incumplimiento

\begin{tabular}{|c|c|c|c|c|c|c|c|c|c|c|c|}
\hline & & \multirow[t]{2}{*}{$B$} & \multirow[t]{2}{*}{$E T$} & \multirow[t]{2}{*}{ Wald } & \multirow[t]{2}{*}{$p$} & \multirow[t]{2}{*}{ O.R } & \multicolumn{2}{|c|}{ 95\% C.I. para O.R } & \multicolumn{2}{|l|}{$R^{2}$} & \multirow[t]{2}{*}{$X^{2}$ Hosmer-Lemeshow } \\
\hline & & & & & & & Inferior & Superior & Cox y Snell & Nagelkerke & \\
\hline \multirow[t]{2}{*}{ Paso 1} & GRAVEDAD & $-0,37$ & 0,035 & 111,904 & 0,000 & 0,691 & 0,645 & 0,74 & \multirow{2}{*}{0,089} & 0151 & 17 780*** \\
\hline & Constante & 1,193 & 0,275 & 18,758 & 0,000 & 3,297 & & & & 0,154 & 15,100 \\
\hline Paso 2 & GRAVEDAD & $-0,525$ & 0,043 & 152,492 & 0,000 & 0,591 & 0,544 & 0,643 & & & \\
\hline & N_DESCRIPTIVA & 0,484 & 0,048 & 100,931 & 0,000 & 1,622 & 1,476 & 1,783 & 0,172 & 0,3 & 12,186 \\
\hline & Constante & $-0,268$ & 0,318 & 0,711 & 0,399 & 0,765 & & & & & \\
\hline Paso 3 & GRAVEDAD & $-0,56$ & 0,045 & 153,001 & 0,000 & 0,571 & 0,522 & 0,624 & & & \\
\hline & CERTEZA & $-0,202$ & 0,03 & 45,229 & 0,000 & 0,817 & 0,77 & 0,866 & $020 ?$ & 0352 & 10027 \\
\hline & N_DESCRIPTIVA & 0,526 & 0,051 & 107,097 & 0,000 & 1,692 & 1,532 & 1,869 & 0,202 & , & 10,021 \\
\hline & Constante & 0,683 & 0,36 & 3,597 & 0,058 & 1,981 & & & & & \\
\hline Paso 4 & GRAVEDAD & $-0,555$ & 0,046 & 146,65 & 0,000 & 0,574 & 0,525 & 0,628 & & & \\
\hline & CERTEZA & $-0,217$ & 0,031 & 48,915 & 0,000 & 0,805 & 0,758 & 0,856 & & & \\
\hline & N_DESCRIPTIVA & 0,527 & 0,052 & 104,498 & 0,000 & 1,694 & 1,531 & 1,874 & 0,223 & 0,389 & $16,957^{*}$ \\
\hline & RETENCION_POLICIA & 0,739 & 0,124 & 35,676 & 0,000 & 2,093 & 1,643 & 2,668 & & & \\
\hline & Constante & 0,462 & 0,365 & 1,601 & 0,206 & 1,587 & & & & & \\
\hline Paso 5 & GRAVEDAD & $-0,489$ & 0,047 & 107,643 & 0,000 & 0,613 & 0,559 & 0,673 & & & \\
\hline & CERTEZA & $-0,215$ & 0,032 & 46,066 & 0,000 & 0,806 & 0,758 & 0,858 & & & \\
\hline & N_DESCRIPTIVA & 0,546 & 0,053 & 105,838 & 0,000 & 1,725 & 1,555 & 1,914 & 0241 & 0421 & 14874 \\
\hline & ACTITUD_OBE & $-0,204$ & 0,036 & 31,541 & 0,000 & 0,815 & 0,759 & 0,875 & 0,241 & 0,421 & 14,004 \\
\hline & RETENCION_POLICIA & 0,728 & 0,127 & 33,076 & 0,000 & 2,072 & 1,616 & 2,656 & & & \\
\hline & Constante & 1,278 & 0,399 & 10,264 & 0,001 & 3,59 & & & & & \\
\hline Paso 6 & GRAVEDAD & $-0,478$ & 0,048 & 99,695 & 0,000 & 0,62 & 0,564 & 0,681 & & & \\
\hline & CERTEZA & $-0,222$ & 0,033 & 46,153 & 0,000 & 0,801 & 0,752 & 0,854 & & & \\
\hline & N_DESCRIPTIVA & 0,577 & 0,054 & 112,96 & 0,000 & 1,78 & 1,601 & 1,98 & & & \\
\hline & ACTITUD_OBE & $-0,199$ & 0,037 & 28,776 & 0,000 & 0,819 & 0,762 & 0,881 & 0,255 & 0,444 & $17,475^{*}$ \\
\hline & RETENCION_POLICIA & 0,722 & 0,131 & 30,456 & 0,000 & 2,058 & 1,593 & 2,66 & & & \\
\hline & $\operatorname{SEXO}(1)$ & $-0,933$ & 0,194 & 23,146 & 0,000 & 0,393 & 0,269 & 0,575 & & & \\
\hline & Constante & 1,524 & 0,408 & 13,969 & 0,000 & 4,591 & & & & & \\
\hline Paso 7 & SEVERIDAD_PERCIBIDA & $-0,255$ & 0,054 & 22,105 & 0,000 & 0,775 & 0,697 & 0,862 & & & \\
\hline & GRAVEDAD & $-0,484$ & 0,049 & 97,332 & 0,000 & 0,616 & 0,56 & 0,678 & & & \\
\hline & CERTEZA & $-0,213$ & 0,033 & 40,515 & 0,000 & 0,808 & 0,757 & 0,863 & & & \\
\hline & N_DESCRIPTIVA & 0,58 & 0,055 & 111,695 & 0,000 & 1,786 & 1,604 & 1,989 & 0268 & 0.467 & 20946 *** \\
\hline & ACTITUD_OBE & $-0,193$ & 0,038 & 25,67 & 0,000 & 0,825 & 0,765 & 0,888 & 0,200 & 0,401 & 20,940 \\
\hline & RETENCION_POLICIA & 0,691 & 0,133 & 26,803 & 0,000 & 1,996 & 1,536 & 2,592 & & & \\
\hline & $\operatorname{SEXO}(1)$ & $-1,054$ & 0,2 & 27,847 & 0,000 & 0,348 & 0,236 & 0,515 & & & \\
\hline & Constante & 2,361 & 0,464 & 25,869 & 0,000 & 10,6 & & & & & \\
\hline Paso 8 & SEVERIDAD_PERCIBIDA & $-0,266$ & 0,055 & 23,31 & 0,000 & 0,766 & 0,688 & 0,854 & & & \\
\hline & GRAVEDAD & $-0,484$ & 0,05 & 94,573 & 0,000 & 0,616 & 0,559 & 0,679 & & & \\
\hline & CERTEZA & $-0,227$ & 0,034 & 44,269 & 0,000 & 0,797 & 0,745 & 0,852 & & & \\
\hline & N_DESCRIPTIVA & 0,587 & 0,056 & 109,378 & 0,000 & 1,799 & 1,612 & 2,008 & & & \\
\hline & ACTITUD_OBE & $-0,197$ & 0,039 & 25,916 & 0,000 & 0,821 & 0,761 & 0,886 & 0,276 & 0,481 & $18,076^{*}$ \\
\hline & RETENCION_POLICIA & 0,702 & 0,136 & 26,486 & 0,000 & 2,017 & 1,544 & 2,635 & & & \\
\hline & SEXO(1) & $-1,187$ & 0,206 & 33,35 & 0,000 & 0,305 & 0,204 & 0,457 & & & \\
\hline & $\operatorname{HIJOS}(1)$ & 0,969 & 0,263 & 13,558 & 0,000 & 2,635 & 1,573 & 4,414 & & & \\
\hline & Constante & 1,73 & 0,495 & 12,223 & 0,000 & 5,64 & & & & & \\
\hline Paso 9 & SEVERIDAD_PERCIBIDA & $-0,271$ & 0,056 & 23,864 & 0,000 & 0,762 & 0,684 & 0,85 & & & \\
\hline & GRAVEDAD & $-0,431$ & 0,054 & 64,189 & 0,000 & 0,65 & 0,585 & 0,722 & & & \\
\hline & CERTEZA & $-0,219$ & 0,035 & 40,406 & 0,000 & 0,803 & 0,75 & 0,859 & & & \\
\hline & N_PRESCRIPTIVA & $-0,098$ & 0,04 & 5,85 & 0,016 & 0,907 & 0,838 & 0,982 & & & \\
\hline & N_DESCRIPTIVA & 0,588 & 0,057 & 107,861 & 0,000 & 1,8 & 1,611 & 2,011 & 0770 & 0487 & $2565 \%$ \\
\hline & ACTITUD_OBE & $-0,191$ & 0,039 & 23,633 & 0,000 & 0,826 & 0,765 & 0,892 & $0,2 \sqrt{9}$ & 0,481 & 25,65 \\
\hline & RETENCION_POLICIA & 0,715 & 0,137 & 27,14 & 0,000 & 2,045 & 1,562 & 2,677 & & & \\
\hline & $\operatorname{SEXO}(1)$ & $-1,182$ & 0,207 & 32,657 & 0,000 & 0,307 & 0,204 & 0,46 & & & \\
\hline & $\operatorname{HIJOS}(1)$ & 0,992 & 0,266 & 13,945 & 0,000 & 2,697 & 1,602 & 4,539 & & & \\
\hline & Constante & 1,898 & 0,506 & 14,052 & 0,000 & 6,675 & & & & & \\
\hline Paso 10 & SEVERIDAD_PERCIBIDA & $-0,264$ & 0,056 & 22,393 & 0,000 & 0,768 & 0,689 & 0,857 & & & \\
\hline & GRAVEDAD & $-0,439$ & 0,054 & 66,217 & 0,000 & 0,645 & 0,58 & 0,717 & & & \\
\hline & CERTEZA & $-0,22$ & 0,035 & 40,329 & 0,000 & 0,802 & 0,75 & 0,859 & & & \\
\hline & N_PRESCRIPTIVA & $-0,105$ & 0,041 & 6,569 & 0,010 & 0,9 & 0,831 & 0,976 & & & \\
\hline & N_DESCRIPTIVA & 0,582 & 0,057 & 105,271 & 0,000 & 1,789 & 1,601 & 1,999 & 0,282 & 0,491 & $20,09^{\text {*** }}$ \\
\hline & ACTITUD_OBE & $-0,192$ & 0,039 & 23,905 & 0,000 & 0,825 & 0,764 & 0,891 & & & \\
\hline & RETENCION_POLICIA & 0,707 & 0,137 & 26,543 & 0,000 & 2,028 & 1,55 & 2,653 & & & \\
\hline & $\operatorname{SEXO}(1)$ & $-1,207$ & 0,208 & 33,65 & 0,000 & 0,299 & 0,199 & 0,45 & & & \\
\hline & $\operatorname{HIJOS}(1)$ & 0,997 & 0,266 & 13,99 & 0,000 & 2,709 & 1,607 & 4,567 & & & \\
\hline
\end{tabular}




\begin{tabular}{|c|c|c|c|c|c|c|}
\hline ESPACIO_AIRE_DIC(1) & $-0,508$ & 0,254 & 4,017 & $0,045 \quad 0,601$ & 0,366 & 0,989 \\
\hline Constante & 2,152 & 0,525 & 16,816 & $0,000 \quad 8,599$ & & \\
\hline
\end{tabular}

Tabla 9 Resumen de la sensibilidad y especificidad de las regresiones logísticas binarias

\begin{tabular}{|c|c|c|c|c|c|}
\hline & & Observado & Prono & & \% Correcto \\
\hline & & & No & Sí & \\
\hline Paso 1 & & No & 1091 & 22 & 98 \\
\hline & & Sí & 171 & 29 & 14,5 \\
\hline & \% Global & & & & 85,3 \\
\hline Paso 2 & & No & 1084 & 29 & 97,4 \\
\hline & & Sí & 158 & 42 & 21 \\
\hline & \% Global & & & & 85,8 \\
\hline Paso 3 & & No & 1078 & 35 & 96,9 \\
\hline & & Sí & 148 & 52 & 26 \\
\hline & \% Global & & & & 86,1 \\
\hline Paso 4 & & No & 1070 & 43 & 96,1 \\
\hline & & Sí & 142 & 58 & 29 \\
\hline & \% Global & & & & 85,9 \\
\hline Paso 5 & & No & 1069 & 44 & 96,00 \\
\hline & & Sí & 133 & 67 & 33,50 \\
\hline & \% Global & & & & 86,5 \\
\hline Paso 6 & & No & 1060 & 53 & 95,2 \\
\hline & & Sí & 124 & 76 & 38 \\
\hline & \% Global & & & & 86,5 \\
\hline Paso 7 & & No & 1066 & 47 & 95,8 \\
\hline & & Sí & 118 & 82 & 41 \\
\hline & \% Global & & & & 87,4 \\
\hline Paso 8 & & No & 1067 & 46 & 95,9 \\
\hline & & Sí & 118 & 82 & 41 \\
\hline & \% Global & & & & 87,5 \\
\hline Paso 9 & & No & 1066 & 47 & 95,8 \\
\hline & & Sí & 115 & 85 & 42,5 \\
\hline & \% Global & & & & 87,7 \\
\hline Paso 10 & & No & 1064 & 49 & 95,6 \\
\hline & & Sí & 113 & 87 & 43,5 \\
\hline & \% Global & & & & 87,7 \\
\hline
\end{tabular}

